ENTREPRENEURSHIP AND SUSTAINABILITY ISSUES

ISSN 2345-0282 (online) http://jssidoi.org/jesi/ 2019 Volume 7 Number 2 (December) http://doi.org/10.9770/jesi.2019.7.2(1)

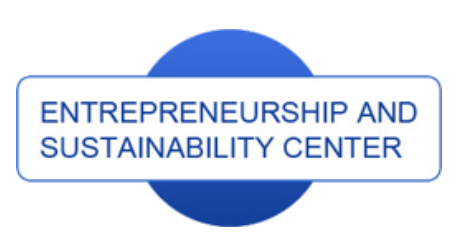

Publisher

http://jssidoi.org/esc/home

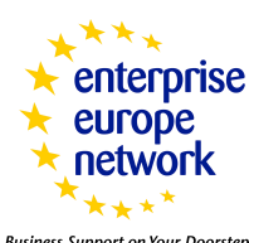

Business Support on Your Doorstep

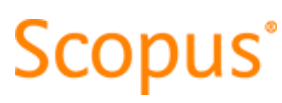

\begin{abstract}
the
\section{EFFECTS OF INNOVATIVE ENTREPRENEURSHIP AND THE INFORMATION SOCIETY ON SOCIAL PROGRESS: AN INTERNATIONAL ANALYSIS}

\author{
Bladimir de la Hoz-Rosales ${ }^{1}$, José Camacho², Ignacio Tamayo ${ }^{3}$ \\ ${ }^{1}$ Economics Program, University of Magdalena, Santa Marta 470001, Colombia \\ ${ }_{2}^{2}$ Department of Spanish and International Economics, University of Granada, 18001 Granada, Spain \\ ${ }^{3}$ Department of Management, University of Granada, 18001 Granada, Spain \\ E-mails: ${ }^{1}$ bdelahoz@unimagdalena.edu.co ; $^{2}$ jcamacho@ugr.es ; ${ }^{3}$ igtamayo@ugr.es
}

Received 15 June 2019; accepted 26 August 2019; published 30 December 2019

\begin{abstract}
The effects of entrepreneurship and information and communication technology (ICT) on countries' development have been extensively studied, mainly from the perspective of their contributions to economic growth. However, from the human development paradigm, economic income is only resource helping people satisfy their economic needs. This study provides new evidence to bridge the gap in our understanding of how entrepreneurship and ICT improve the quality of people's lives. To achieve this goal, we use the capabilities approach as a theoretical framework. The empirical analysis was conducted using ordinary least squares with a sample of countries to provide evidence that innovative entrepreneurship, as measured by the Global Entrepreneurship Monitor, has a positive relationship with human development, as measured by the Social Progress Index. The results show that ICT, as measured by the Networked Readiness Index, is positively related to social progress, indicating that ICT is a tool that helps people improve their ability to lead the life they desire. Finally, we find that ICT boosts the positive effect of innovative entrepreneurship on social progress, and thus, that enhancing ICT, and with it, entrepreneurial innovation activity, improves the quality of life.
\end{abstract}

Keywords: social progress; information society; information and communication technologies; innovative entrepreneurship; theory of human development

Reference to this paper should be made as follows: De la Hoz-Rosales, B.; Camacho, J.; Tamayo, I. 2019. Effects of innovative entrepreneurship and the information society on social progress: an international analysis, Entrepreneurship and Sustainability Issues 7(2): 782-813. http://doi.org/10.9770/jesi.2019.7.2(1)

JEL Classifications: O14, O31, M13; D83; L886

Additional disciplines: Information and Communication 


\section{ENTREPRENEURSHIP AND SUSTAINABILITY ISSUES}

ISSN 2345-0282 (online) http://jssidoi.org/jesi/

2019 Volume 7 Number 2 (Decembre)

http://doi.org/10.9770/jesi.2019.7.2(1)

\section{Introduction}

Academics in the field of social sciences have historically been motivated to study entrepreneurship (Landström et al. 2012; Urbano et al. 2019). Research on the effects of entrepreneurship has focused primarily on establishing the impacts on economic growth, productivity, and employment (Acs, Szerb 2007; Carree et al. 2007; Chen et al. 2018; Perényi, Losoncz 2018). Interest in understanding the effects of entrepreneurship on the economy grew at the beginning of the 1980s when the US study of job creation by Birch (1981) concluded that small and mediumsized enterprises (SMEs) were the main agents creating employment (Audretsch 2007; Gnyawali, Fogel 1994; Urbano, Alvarez 2014).

From the perspectives of economic growth, economic development, and regional development, the effects of entrepreneurship depend primarily on factors such as a country's stage of development, the economic sector in which the entrepreneurial activity is performed, and the motivations that lead people to become entrepreneurs (Acs et al. 2012; Acs, Storey 2004; Audretsch et al. 2008; Coulibaly et al. 2018; Núñez-Cacho et al. 2018; Urbano, Aparicio 2016). Two main motivations have been identified: the exploitation of an opportunity to provide the goods and services required by society and the need to be self-employed as a subsistence mechanism (Bosma et al. 2017). The type of entrepreneurship generating the greatest impact on economic growth and development is opportunity entrepreneurship oriented toward innovation (Acs, Storey 2004; Audretsch 2012; Baumol 1993; Bosma et al. 2017; Cuéllar-Gálvez et al. 2018; Demartini 2018; Reynolds 2017; Schumpeter 1939; Shane, Venkataraman 2000; Urbano et al. 2016; Wennekers et al. 2005).

Kleine (2010) indicated that since the second half of the 20th century, discussions about countries' development have been guided by different perspectives. These include theories aligning development and economic growth (Lewis 1954; Myrdal 1957; Rostow 1960), theories arguing that the origin of dependency and inequalities are characteristic of a capitalist system (Frank 1967), and alternative approaches to development that recognize ecological, economic, and social goals (Chambers 1983). One of the most influential theories that counteracts the view of development focused on economic growth is the capabilities approach (CA) proposed by Sen (Kleine 2010; Robeyns 2005). This approach defines development as "a process of expanding the freedoms that people enjoy" (Sen 1999, p. 3) to lead the kind of life they have reason to value (Drèze and Sen 2002). In this theory, economic growth and technology are important means for people to achieve and live the life that they value (Drèze, Sen 2002; Robeyns 2005).

Most studies that explain the effects of entrepreneurship on countries' development have focused on determining their contribution to economic growth. Gross domestic product (GDP), an indicator of economic growth, is used to determine how rates of entrepreneurship affect this indicator. The literature review by Gries and Naudé (2011) showed that few studies have been published on the impact of entrepreneurship on development beyond its contribution to economic growth, highlighting the need for more research that provides evidence to bridge this gap.

Accordingly, the first goal of this study is to present new evidence on the relationship between entrepreneurship and human development (HD), which motivated the following question: How does entrepreneurship influence social progress? To answer this question, the CA is used as the theoretical framework, which implies that to determine the effects of entrepreneurship on $\mathrm{HD}$, a first analysis should identify if entrepreneurs are engaging in this activity because it is what they really want to do and be or because it is imposed by their socioeconomic circumstances. A second analysis must focus on the normative aspect of entrepreneurship to identify whether this type of activity positively or negatively affects HD. Therefore, it is necessary to evaluate the relationship between entrepreneurship rates and multidimensional measures of HD. 


\section{ENTREPRENEURSHIP AND SUSTAINABILITY ISSUES}

ISSN 2345-0282 (online) http://jssidoi.org/jesi/ 2019 Volume 7 Number 2 (Decembre) http://doi.org/10.9770/jesi.2019.7.2(1)

Since the first decade of the 21st century, the entrepreneurship rates in around 100 countries has been measured by the Global Entrepreneurship Monitor (GEM), which ranks as the most important entrepreneurship monitor globally (Reynolds 2017; Reynolds et al. 2005). GEM data are the main source of information for conducting empirical studies that attempt to explain the causes and effects of entrepreneurship (Urbano, Alvarez 2014). Therefore, in this study, we used the data on innovative entrepreneurship published by the GEM. When measuring $\mathrm{HD}$, the main limitation is the scarcity of multidimensional indexes that can capture the extent to which people satisfy their needs (Stiglitz et al. 2009). Another limitation is associated with the absence of time series data on multidimensional indexes to measure quality of life (Porter et al. 2017).

Following the publication of Sen's approach, the United Nations Development Programme (UNDP) adopted the concept of HD in 1990, which is now measured globally using the Human Development Index (HDI) (UNDP 2016). The use of this index has drawn criticism since the measure is only based on three dimensions: a long and healthy life, access to knowledge, and a decent standard of living (UNDP 1990, 2015a). Based on this, the Social Progress Imperative - guided by the studies by Sen et al. (UNDP 2015a) among others - created a new quality of life index in 2013. Termed the Social Progress Index (SPI), this index is calculated from 53 indicators classified into three dimensions of social progress: basic human needs, foundations of well-being, and opportunity. The SPI is thus considered to be an internally consistent approach to measuring HD (Porter et al. 2017; Stanojević, Benčina 2019). Therefore, in this study, we use the SPI as the measure of HD.

The second goal of this study is to understand the effect of information and communication technology (ICT) on countries' development. Sen (2010) argued that ICT is responsible for the creation of an interactive global culture. The positive use of ICT, such as using it to expand human freedoms, enables both greater efficiency in various human activities and a stronger ability to fight government repression of individual freedoms. Kleine (2010) argued, however, that the discourse on ICT for developing continues focuses too heavily on economic growth, with severe limitations for capturing the impact of these resources on people's quality of life. Similarly, Heeks (2010) indicated the need for more evidence on the impact of ICT on development, especially studies based on theories supporting HD. Likewise, Thapa and Saebø (2014) argued for quantitative research to understand the effects of the relationship between ICT and development and Oosterlaken (2012) recommended performing empirical studies to analyze ICT at the micro and macro levels for politicians, professionals, and activists responsible for development. Johnston et al. (2015) also found that insufficient studies have elucidated ICT's contribution to solving social problems.

In this study, the Networked Readiness Index (NRI) serves as the measure of ICT usage and adoption. The NRI, created by the World Economic Forum, the Business School for the World, and Cornell University, seeks to measure countries' readiness to exploit the benefits of emerging ICT and potential to exploit the opportunities presented by the digital revolution (World Economic Forum 2016b). According to James (2012), the NRI is the most popular and frequently used measurement for comparing and measuring ICT usage in a country.

The first contribution of this study in the analysis of the relationship between entrepreneurship and social progress is to identify the type of entrepreneurship that improves quality of life. The usage of the SPI as a measure of HD allows us to provide new evidence about the incidence of innovative entrepreneurship in improving quality of life from a multidimensional perspective, beyond its contribution to economic growth. The second contribution is demonstrating the impact of ICT on HD, using the NRI as the primary measure. We also explore the interaction of entrepreneurship and ICT usage on HD.

The remainder of the paper is organized as follows. We first present the conceptual framework and formulate the hypotheses in Section 2. Section 3 discusses the methodology used and information sources. Section 4 provides the results and Section 5 presents the conclusions, recommendations, and political implications. 


\section{ENTREPRENEURSHIP AND SUSTAINABILITY ISSUES}

ISSN 2345-0282 (online) http://jssidoi.org/jesi/ 2019 Volume 7 Number 2 (Decembre) http://doi.org/10.9770/jesi.2019.7.2(1)

\section{Conceptual framework and hypotheses development}

\subsection{The capabilities approach (CA)}

Since the 1950s, GDP per capita has been used to measure development (Kuznets 1955). Research has recognized, however, that pure economic indicators do not represent the full multidimensionality of development (Jones, Klenow 2010; Naudé et al. 2009; Stiglitz et al. 2009). The theory of social choice developed by Sen during the 1970s states that there are regulatory reasons for modifying welfare economics and the exclusive dependence on income and wealth as indicators of HD. Based on this, Anand and Sen (2000) argued that focusing on variables such as GDP per capita and national wealth to measure levels of development perpetuates the traditional approach oriented to opulence, whereas the search for well-being should focus on the improvement in positive freedoms or people's capabilities (Sen 1999).

Atkinson (2002) and Bourguignon and Chakravarty (2003) found broad consensus that multiple factors cause a deprivation of goods and services. Therefore, addressing poverty through people's income level is insufficient. In this sense, other attributes associated with the expansion of capabilities should be analyzed. The CA provides the tools to analyze inequality based on its multidimensionality. For Sen (1999), HD is associated with people's capability to live the kind of life that they have reason to value.

The philosophical thinking of the CA has provided the basis for creating a paradigm that seeks to redirect the discussion about the concept of wealth to what people are able to do or be. The CA differs from the utilitarian approach, which explains people's level of satisfaction based on the amount of goods and services that enable them to have a particular lifestyle (Fukuda-Parr 2003; Robeyns 2017). The CA bases its analysis on the concepts of capabilities, functioning, achieved functioning, and agency (Drèze, Sen 1991; Matthews, Field 2001; Sen 1981 1995, 1998, 1999, 2005, 2009; Sugden, Sen 2006). Capabilities are what people are free to do, functioning is what people actually do (Anand et al. 2009), achieved functioning is the result of the actions that a person enjoys at a certain point in time, and agency refers to the ability of a person to pursue goals they have voluntarily set. A person without agency is one who performs crucial activities in their life as an obligation (Alkire 2005).

Robeyns (2017) developed a revised version of the CA that validates the concepts of capabilities, functioning, and agency and stresses the importance of including other fundamental elements that enable people to do and be what they desire. These elements include resources (income from labor, wealth, transfers, profits, and non-market production), the structural limitations associated with institutional conditions (social and legal norms, social institutions, and other people's behavior and characteristics), and the conversion factors related to the different skills that people must have to transform resources into functioning. Appendix A presents a schematic view of the core concepts in the CA, formulated by Robeyns (2017).

According to the above, social conversion factors and structural limitations play predominant roles in expanding capabilities or freedoms. In the new institutional economic theory outlined by North $(1990,2005)$, these elements constitute institutional conversion factors. For Drèze and Sen (2002), expanding people's freedoms or capabilities depends mostly on interaction processes with other people and the role of the state, reflected through its institutions. These authors thus recommended paying special attention to the opportunities influenced by structural constraints.

\subsection{Innovative entrepreneurship and the CA}

According to Alkire (2008), the CA has two practical uses: evaluation (i.e., enabling a comparison of situations) and its proposal, which establishes policy recommendations that can expand capabilities. Sen's practical contribution to the HD paradigm has been of such significance globally that the United Nations (UN) has used the 
CA since 1990 as the theoretical framework for the universal promulgation of the concept of HD (UNDP 1990). This concept includes the expansion of people's capabilities so that political, economic, and social freedoms provide them with "opportunities for being creative and productive" (UNDP 1990, p. 10). This definition highlights the need for people to develop their creativity, which motivates them to innovate for the production of goods and services, potentially approaching the concept of entrepreneur suggested by Schumpeter (1939). Similarly, the UN's vision of the impact of entrepreneurship on HD is seen in the reports it has issued (Table 1). The review shows a close relationship between entrepreneurship and HD, with the 2015 report in particular highlighting the benefits of creative entrepreneurship and innovation, which may positively impact society (UNDP 2015b).

Table 1. Relationship between entrepreneurship and HD

\begin{tabular}{|c|c|c|}
\hline Year(s) & Name of report and subject analyzed & $\begin{array}{l}\text { Link between entrepreneurship and } \\
\text { HD }\end{array}$ \\
\hline 1990 & $\begin{array}{l}\text { Human Development Report: Definition of } \\
\text { Development. }\end{array}$ & $\begin{array}{l}\text { Increasing opportunities and } \\
\text { capabilities for productivity and } \\
\text { creativity (UNDP 1990). }\end{array}$ \\
\hline \multirow[t]{3}{*}{1993} & \multirow[t]{3}{*}{$\begin{array}{l}\text { Human Development Report: Measures to } \\
\text { Ensure People-Friendly Markets. }\end{array}$} & $\begin{array}{l}\text { Promotes free enterprise as a } \\
\text { mechanism for "unleashing human } \\
\text { creativity and entrepreneurial ability." }\end{array}$ \\
\hline & & $\begin{array}{l}\text { Entrepreneurship produces benefits not } \\
\text { only for the individual but for society } \\
\text { as a whole, such as job creation. }\end{array}$ \\
\hline & & $\begin{array}{l}\text { Boost business capacity, making it } \\
\text { easier for entrepreneurs to obtain } \\
\text { financial capital (UNDP 1993). }\end{array}$ \\
\hline 2002 & $\begin{array}{l}\text { Human Development Report: Deepening } \\
\text { Democracy in a Fragmented World: } \\
\text { Broadening the Scope of Human } \\
\text { Development. }\end{array}$ & $\begin{array}{l}\text { Entrepreneurial spirit can make } \\
\text { markets more dynamic (UNDP 2002). }\end{array}$ \\
\hline $2007-2008$ & $\begin{array}{l}\text { Human Development Report: Fighting } \\
\text { Climate Change: Human Solidarity in a } \\
\text { Divided World: The Traps of Low Human } \\
\text { Development. "Before-the-Event" Losses in } \\
\text { Productivity. }\end{array}$ & $\begin{array}{l}\text { Poor people are not poor because they } \\
\text { are less enterprising. They are less } \\
\text { enterprising because of their aversion } \\
\text { to risk and the impossibility of bearing } \\
\text { the financial costs associated with the } \\
\text { risks of setting up a new business } \\
\text { (UNDP 2007). }\end{array}$ \\
\hline \multirow[t]{3}{*}{2015} & \multirow{3}{*}{$\begin{array}{l}\text { Human Development Report: Work for } \\
\text { Human Development: Policies for Improving } \\
\text { Human Development Through Work. }\end{array}$} & $\begin{array}{l}\text { Establish government policies to } \\
\text { support young businesspeople. }\end{array}$ \\
\hline & & $\begin{array}{l}\text { Requirements to ensure that creativity } \\
\text { and innovation can flourish and } \\
\text { innovate inclusively, increase } \\
\text { democratic creativity and innovation } \\
\text { for the public good. }\end{array}$ \\
\hline & & $\begin{array}{l}\text { "Job creation and enterprise } \\
\text { development provide an income and a } \\
\text { livelihood for the population, are } \\
\text { essential instruments for fairness, form } \\
\text { spaces for participation and enhance } \\
\text { self-esteem and dignity" (UNDP } \\
\text { 2015a). }\end{array}$ \\
\hline
\end{tabular}

Source: The authors, based on Human Development Reports 1990-2016 


\section{ENTREPRENEURSHIP AND SUSTAINABILITY ISSUES}

ISSN 2345-0282 (online) http://jssidoi.org/jesi/ 2019 Volume 7 Number 2 (Decembre) http://doi.org/10.9770/jesi.2019.7.2(1)

However, few studies published in high-impact journals provide information on the relationship between entrepreneurship and HD. One important contribution was by Gries and Naudé (2011), who proposed a theoretical framework that could relate entrepreneurship to HD based on the CA approach. For these authors, entrepreneurship is a functioning because it is the result of the economic or work activity in which people are involved. They argued that entrepreneurship, as a resource, has the capacity to generate new job opportunities in addition to facilitating other functionings. The link between entrepreneurship and agency is associated with allowing a prospective entrepreneur to detect an opportunity and materialize it freely and spontaneously. The act of starting a business can be considered, in terms of Robeyns (2017), to be a context-dependent functioning since social conversion factors and structural constraints significantly influence its achievement.

Notably, the CA, before analyzing functionings from a normative perspective, suggests its neutrality be recognized, which refers to the action (functioning) of generating results that can be valued positively or negatively. Therefore, if an action is evaluated negatively, it is not excluded as a functioning (Robeyns 2017). Accordingly, the analysis of entrepreneurship as a functioning implies recognizing its neutrality; in other words, being an entrepreneur does not depend on the impact of the business on society, but on the action of creating a new business itself. Once the entrepreneurial action has taken place, the person who carries it out and society establish value judgments about its expediency.

Likewise, the CA constitutes a theory of well-being and therefore any account of the capability or explanation developed within the framework of this approach must tend toward well-being (Robeyns 2017). This position is supported by Sen $(1985,1993)$. Thus, when introducing the normative part of entrepreneurship, from the CA perspective, this human activity must be viewed as a refined functioning; in other words, one that is chosen over several possibilities (Sen 1987). Entrepreneurship must be innovative and productive in the sense of Baumol (1990). Gries and Naudé (2011) defined it as "the resources, processes, and state of being through and in which individuals utilize positive opportunities in the market by creating and growing new business firms" (p. 217). This definition is normative in the CA framework because it values or validates only entrepreneurial activities that have a positive impact on quality of life. Gries and Naudé (2011) argued that their definition tries to go beyond the concepts formulated by Schumpeter (1939) and Kirzner (1973) to recognize that the benefits obtained by an entrepreneur not only provide monetary gain, but also are oriented toward achieving the kind of life desires and generating a surplus for society as a whole.

The GEM classifies entrepreneurs into different types according to their motivations for becoming entrepreneurs (opportunity vs. need) and type of economic activity (Reynolds et al. 2005). Based on the recognition of the conceptual neutrality of the functionings, necessity entrepreneurship is a functioning. However, its assessment from the normative perspective cannot be extended beyond the definition, that is, as a means of subsistence for the person who performs it (Reynolds et al. 2005). The results of some studies of the impact of being an entrepreneur by necessity indicate that when a person is obliged to perform an activity as the sole option for subsistence, it restricts his or her agency, which can cause dissatisfaction because he or she is unable to exercise his or her free will and do what he or she really desires (Binder, Coad 2016; Block et al. 2015). Similarly, according to Harbi and Grolleau (2012), necessity entrepreneurship has a questionable impact on the happiness of people. According to Gries and Naudé (2011), it restricts human agency because it is solely a means of subsistence for the person who performs it.

As mentioned in the Introduction, however, opportunity entrepreneurship, especially innovative entrepreneurship, contributes to economic growth and job creation (Acs, Storey 2004; Audretsch 2012; Baumol 1993; Bosma et al. 2017; Cuéllar-Gálvez et al. 2018; Demartini 2018; Reynolds 2017; Schumpeter 1939; Shane, Venkataraman 2000; Urbano et al. 2016; Wennekers et al. 2005). This type of entrepreneurship possesses the characteristics closest to the concept of entrepreneur adopted in this study, because such entrepreneurs have (i) the necessary economic and non-economic resources to be transformed into innovative products or services; (ii) the necessary 


\section{ENTREPRENEURSHIP AND SUSTAINABILITY ISSUES}

ISSN 2345-0282 (online) http://jssidoi.org/jesi/ 2019 Volume 7 Number 2 (Decembre) http://doi.org/10.9770/jesi.2019.7.2(1)

skills and knowledge to manage their business activities; (iii) the necessary freedom to transform the resources and bring them to the market as final goods or finished products. At this point, entrepreneurs can use their liberties to create a new firm because it is allowed under the structural restrictions; and (iv) the recognition of this action as a functioning. Further, they have (v) agency because creating a new enterprise is a voluntary act that allows entrepreneurs to fulfill their goal of achieving the life they desire. The result of this action generates a positive social impact, as it creates new employment options and new goods or services to cater for the needs of others.

Therefore, entrepreneurship activities based on an opportunity and oriented toward innovation may contribute significantly to social progress, giving rise to our first hypothesis:

Hypothesis 1 (H1). Innovative entrepreneurship is positively related to social progress.

\subsection{ICT and the CA}

Understanding development as the expansion of capabilities does not mean denying the importance of the resources (Robeyns 2017) proceeding from economic growth or technological progress as tools that encourage HD. The effectiveness of income and technology should therefore be evaluated according to their impact on capabilities expansion (Drèze, Sen 2002). Sen (2010) recognized ICT as "an interactive culture across the world" that transcends the debate on local vs. global knowledge. ICT is equally absorbed by both people who defend modernity and globalization and people who defend local culture. Sen also argued that the questions we should ask about ICT usage should focus on how ICT can help people be more efficient in their work and how ICT usage can be important for expanding capabilities to win battles for freedom and against the continuity of repressive governments.

Several authors have analyzed the impact of ICT on HD using the CA. Interest is growing in demonstrating the role of ICT in HD using the CA approach, since ICT can contribute directly and simultaneously to the expansion of human capabilities in different areas (e.g., health, education, recreation, and as a means of subsistence). Oosterlaken (2012) showed that ICT "might thus be seen as the ultimate embodiment of the ideal of the capability approach, that we ought to promote a variety of capabilities and leave it up to empowered individuals which functioning to realize, depending on their idea about a good life" (pp. 12-13). Similarly, Kleine (2010) stated that ICT is a useful tool for improving people's capability to make effective decisions that enable them to achieve their desired results. Given the potential to expand opportunities and facilitate the process of choice, the CA is especially interesting for those who study and work in the field of ICT and development.

The literature review by Lwoga and Sangeda (2019) on the impact of ICT on quality of life enhancement in developing countries highlighted the CA as one of the main reference frameworks used since the 1990s to explain this relationship. The prevalence of the CA stems from its broader view, including the social dimensions of development where ICT usage can improve living conditions. Despite multiple evaluations, the review showed that the contribution of ICT to HD remains debatable, however. In an extensive review of the link between ICT and development analyzed using the CA approach, Thapa and Saebø (2014) found that ICT may contribute to expanding capabilities, particularly to what Sen (1999) called instrumental freedom, which is related to guarantees of transparency.

From the perspective of international organizations oriented toward development, the UN uses a number of its Human Development Reports to recommend that national governments create or strengthen the institutional framework that encourages the use and adoption of ICT as tools to expand capabilities. Table 2 shows how ICT contributes to HD. 


\section{ENTREPRENEURSHIP AND SUSTAINABILITY ISSUES}

ISSN 2345-0282 (online) http://jssidoi.org/jesi/ 2019 Volume 7 Number 2 (Decembre) http://doi.org/10.9770/jesi.2019.7.2(1)

Table 2. Relationship between ICT and HD

\begin{tabular}{|c|c|c|}
\hline Year & Name of report & Link between ICT and HD \\
\hline 1992 & Human Development Report & $\begin{array}{l}\text { The significance of ICT, as a means } \\
\text { that narrows the gap between the } \\
\text { richest and poorest, is in the } \\
\text { international agenda on development } \\
\text { because the adoption and use of ICT } \\
\text { promotes sustainable HD (UNDP } \\
\text { 1992). }\end{array}$ \\
\hline 1998 & Human Development Report & $\begin{array}{l}\text { Broadening access to schooling and } \\
\text { ICT has expanded people's potential, } \\
\text { thereby facilitating their development } \\
\text { within society (UNDP 1998). }\end{array}$ \\
\hline 1999 & Human Development Report & $\begin{array}{l}\text { The use of new ICT is driving } \\
\text { globalization; that is, the fusion of } \\
\text { computing and communications } \\
\text { through the Internet has broken the } \\
\text { barriers of cost, time, and distance. } \\
\text { Therefore, this fusion has raised } \\
\text { efficiency in various human } \\
\text { interaction activities (UNDP 1999). }\end{array}$ \\
\hline 2001 & $\begin{array}{l}\text { Human Development Report: } \\
\text { Making New Technologies Work } \\
\text { for Human Development }\end{array}$ & $\begin{array}{l}\text { The democratization of all } \\
\text { technological advances has been } \\
\text { through giving people access to them. } \\
\text { ICT is a tool used to improve quality } \\
\text { of education and facilitate the entry of } \\
\text { SMEs into markets (UNDP 2001). }\end{array}$ \\
\hline 2003 & $\begin{array}{l}\text { Human Development Report: } \\
\text { Millennium Development Goals: A } \\
\text { Compact Among Nations to End } \\
\text { Human Poverty }\end{array}$ & $\begin{array}{l}\text { ICT plays a major role in meeting the } \\
\text { Millennium Development Goals, } \\
\text { especially Goal No. 8: Develop a } \\
\text { global partnership for development, } \\
\text { for which target No. } 18 \text { was } \\
\text { established in cooperation with the } \\
\text { private sector, making the benefits of } \\
\text { new technologies available, especially } \\
\text { ICT. As of 2003, statistics on ICT use } \\
\text { around the world have been included } \\
\text { in the Human Development Reports } \\
\text { (UNDP 2003). }\end{array}$ \\
\hline 2013 & $\begin{array}{l}\text { Human Development Report: The } \\
\text { Rise of the South: Human Progress } \\
\text { in a Diverse World }\end{array}$ & \multirow{4}{*}{$\begin{array}{l}\text { ICT is recognized as a means to } \\
\text { expand human capabilities (UNDP } \\
\text { 2013). It is important for people's } \\
\text { control of public bodies, which are } \\
\text { required to publish on their websites } \\
\text { all information associated with their } \\
\text { functioning (UNDP 2014, 2015a, } \\
\text { 2016). }\end{array}$} \\
\hline 2014 & $\begin{array}{l}\text { Human Development Report: } \\
\text { Sustaining Human Progress: } \\
\text { Reducing Vulnerabilities and } \\
\text { Building Resilience }\end{array}$ & \\
\hline 2015 & $\begin{array}{l}\text { Human Development Report: Work } \\
\text { for Human Development }\end{array}$ & \\
\hline 2016 & $\begin{array}{l}\text { Human Development Report: } \\
\text { Human Development for Everyone }\end{array}$ & \\
\hline
\end{tabular}

Source: The authors, based on Human Development Reports 1990-2016.

Similarly, the UN has promoted the Information Society. At its 2002 summit (General Assembly of the United Nations 2002), representatives of 174 countries approved the creation of the Information Society, considering the Universal Declaration of Human Rights, especially the fundamental right of every individual to freedom of 


\section{ENTREPRENEURSHIP AND SUSTAINABILITY ISSUES}

ISSN 2345-0282 (online) http://jssidoi.org/jesi/ 2019 Volume 7 Number 2 (Decembre) http://doi.org/10.9770/jesi.2019.7.2(1)

opinion and expression. The Information Society was born as a comprehensive and development-oriented institution whose main goal is to improve people's quality of life by promoting ICT adoption and use (International Telecommunication Union \& United Nations 2005). The UN Human Rights Council also recognizes "the global and open nature of the Internet as a driving force in accelerating progress towards development in its various forms" (General Assembly of the United Nations 2012), and access to this medium is seen as an extension of the fundamental right to freedom of expression. Based on International Telecommunication Union (2008) statistics, $48.6 \%$ of the global population had access to and used the Internet in 2017. The General Assembly of the United Nations (2015) approved a general examination of the Information Society's global reach. The UN recognizes the importance of ICT in achieving the 17 Sustainable Development Goals by 2030. The evaluation also highlights the digital economy as an important and growing part of the world economy (General Assembly of the United Nations 2015).

Another international organization that advocates the importance of ICT in development is the World Economic Forum, whose 2016 Global Information Technology Report (World Economic Forum 2016b) argued that ICT constitutes the backbone of developments occurring in the fourth industrial revolution. This revolution has fostered an exponential increase in capabilities for processing and storing information as well as for making this knowledge accessible to people as never before, facilitating better HD in the future.

Since 2001, the Global Information Technology Report series published by the World Economic Forum, INSEAD, and Cornell University has measured the drivers of the ICT revolution at the global level using the NRI. The NRI has evolved over time and now evaluates the state of network preparation using 53 individual indicators. For each of the 139 economies studied, the NRI identifies areas of priority for the use of ICT for better socioeconomic development (World Economic Forum 2016b). It also delivers information on the individual, family, business, and public adoption and use of the Internet, cell phones, personal computers, telephone network infrastructure, and Internet servers with secure access as well as the use of virtual networks (World Economic Forum 2016b). As mentioned in the Introduction, the NRI is the most frequently used measurement to identify countries' use and adoption of ICT.

Based on the above, we propose the following hypothesis on the virtues of ICT as an instrument that improves quality of life:

Hypothesis 2 (H2). ICT adoption and use are positively related to social progress.

\subsection{ICT, entrepreneurship, and the CA}

Hamel (2010) suggested that the effectiveness of ICT in improving quality of life can be increased to the extent that its use and adoption is accompanied by strategies or programs that favor human activities. Similarly, Kleine (2010) stated that ICT is a useful tool for improving people's capability to make effective decisions that enable them to achieve their desired results. According to the above, the analysis of the effects of using ICT on entrepreneurial activities should begin by determining how to improve the living conditions of entrepreneurs when they decide to use such technology. A study conducted in Indonesia reported that the use of cell phones by blind microentrepreneurs had a fundamental role in the perceived well-being of the people analyzed (Anwar, Johanson 2015). This study also concluded that cell phones facilitated functionings that the participants valued greatly. The same conclusion was reached by the authors on cell phone use for a sample of religious women and microentrepreneurs in Indonesia (Anwar, Johanson 2014). Kemal (2019) argued that the use of ICT allows microentrepreneurs to obtain sustainable livelihoods, such as increased income and profits, access to new markets and market information, less dependence on physical/natural resources, and risk reduction. 


\section{ENTREPRENEURSHIP AND SUSTAINABILITY ISSUES}

ISSN 2345-0282 (online) http://jssidoi.org/jesi/ 2019 Volume 7 Number 2 (Decembre) http://doi.org/10.9770/jesi.2019.7.2(1)

From the perspective of improving society's quality of life, as a result of the actions undertaken by entrepreneurs on the basis of ICT use, several studies have found that an SME's usage of ICT reduces multidimensional poverty by creating new jobs and facilitating enterprise subsistence (Duncombe 2003; Makoza, Chigona 2012; Mbuyisa, Leonard 2017). Similarly, the US government has recognized that ICT usage in nascent enterprises is important for improving social progress, so it created the Digital Freedom Initiative to help entrepreneurs and small businesses make better use of ICT to create jobs and improve the standard of living of locals (Ferrer 2009). Given the growing significance of the digital economy, the 28 member countries of the European Union (EU) approved the creation of a digital single market in 2015 to create digital opportunities for people and companies using the Internet and digital technologies. According to studies performed by the EU, the creation of the digital single market would reduce regulatory barriers, enabling a transition from 28 national markets into a single market, which, when fully functional, could contribute $€ 415$ billion to the EU economy and create hundreds of thousands of new jobs (European Commission 2015). Mathew (2010) argued that ICT allows women entrepreneurs to increase their participation in the growth and development of the nation's economy: "The extended use of ICT will help the entrepreneur in creating advantage, research; participate in the global world of business for technology transfer, training, collaboration, and development initiatives at the global level" (p. 1). ICT is thus a driving force in the creation and dissemination of new products and services (Alderete 2017).

Within the CA framework, to determine the importance of public or private intervention in the enhancement of quality of life, the relationship between resources and functionings needs to be studied (Robeyns 2017). In this sense, innovative entrepreneurship is a functioning and ICT is a resource. Therefore, the effectiveness of ICT and innovative entrepreneurship on social progress can be measured more accurately by relating them. Sen (1999) suggested that the quality of people's lives depends on what they are capable of doing or being with the resources to which they have access. Regarding the use of ICT, as mentioned in Section 2.3, Sen (2010) argued that the question we should ask is how these resources can help people be more efficient in their work and how their usage can expand capabilities.

According to the above, the relationship between ICT and innovative entrepreneurship must be analyzed from the perspective of ICT's influence on the efficiency of entrepreneurial activity to improve quality of life. In this sense, the analysis of the relationship between ICT and innovative entrepreneurship and their effects on social progress uses their interaction; that is, ICT does not cause entrepreneurship, but these resources increase the effects of entrepreneurship on social progress. Therefore, ICT is a resource that moderates the impact of innovative entrepreneurship on social progress. Baron and Kenny (1986) argued that "moderators and predictors are at the same level in regard to their role as causal variables antecedent or exogenous to certain criterion effects. That is, moderator variables always function as independent variables, whereas mediating events shift roles from effects to causes, depending on the focus of the analysis" (p. 1173).

The analysis of innovative entrepreneurship in Section 2.2. indicates that it has a positive impact on social progress because it creates new goods and services as well as jobs, contributing to economic growth, and is a functioning that improves quality of life. Similarly, as discussed in Section 2.3, ICT adoption/use is positively related to social progress. Taking into account that both effects are positive, we infer that when innovative entrepreneurs use ICT, there is an increase in the effect of their activity on social progress. In this sense, the following hypothesis is suggested:

Hypothesis $3(\mathrm{H} 3)$. The effect of innovative entrepreneurship on social progress is higher when it is moderated by ICT.

Figure 1 summarizes the hypotheses of the present study. Initially, we propose that innovative entrepreneurship has a positive effect on social progress (H1). Then, we suggest that the use and adoption of ICT has a positive effect on social progress (H2) and, finally, the effects of innovation entrepreneurship on social progress increase 
when they are moderated by ICT (H3). For this last hypothesis, a dotted line is used to indicate that ICT moderates the effects of innovation on social progress.

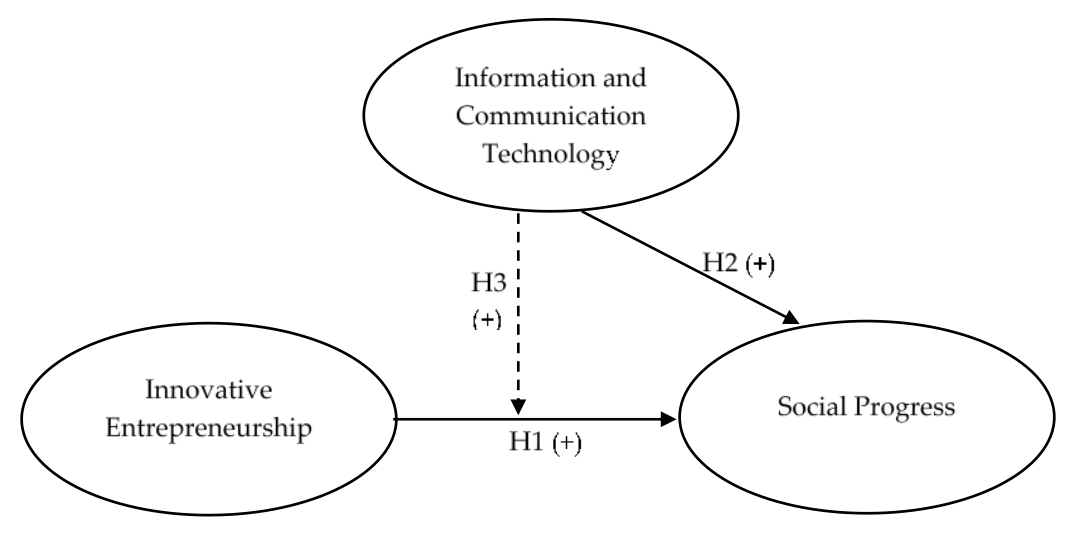

Fig.1. Effect of innovative entrepreneurship on social progress, of ICT on social progress, and of innovative entrepreneurship on social progress moderated by ICT

Source: the authors

\section{Materials and methods}

\subsection{Materials}

\subsubsection{Dependent variable}

Since 1990, the indicator most frequently used to measure HD has been the HDI (UNDP 1990, 2015a). Since the CA aims to expand the freedoms that people enjoy to lead the kind of life they have reason to value (Sen 1999), the HDI has been criticized for not including additional indicators related to the range of functioning that contributes to quality of life (Alkire, Foster 2011; Anand et al. 2009; Hirai 2017; Klugman et al. 2011; Naudé 2013). In 2013, the non-profit Social Progress Imperative, under the leadership of Michael Porter at Harvard University and Scott Stern at the Massachusetts Institute of Technology, published the first version of the SPI as a tool to measure quality of life as an alternative to the HDI. In 2015, after discussions with experts globally on the shortcomings of using GDP per capita as an indicator of development (Porter, Stern 2013; Stern et al. 2017), this foundation launched a new version of the SPI. Based on the theoretical concepts of development formulated by Sen and colleagues (see Porter, Stern 2013), the SPI was defined as "the capacity of a society to meet the basic human needs of its citizens, establish the building blocks that allow citizens and communities to enhance and sustain the quality of their lives, and create the conditions for all individuals to reach their full potential" (Stern et al. 2017, p. 3).

The SPI is structured into three elements: dimensions, components, and indicators. The dimensions are the three sub-indexes (basic human needs, foundations of well-being, and opportunity). Each dimension is composed of four components and each component is composed of indicators aggregated to each component through exploratory factor analysis using principal component analysis. Appendix B presents the structure of this index. To measure the reliability and consistency of the SPI scales, the creators calculated the Cronbach's alpha for the indicators of each component. After performing the principal component analysis for each component, they 
assessed goodness of fit using the Kaiser-Meyer-Olkin measure of sampling adequacy. Stern et al. (2014) provided a detailed analysis of the rigorous process for creating and validating the SPI. As an additional measure of the reliability of the SPI scales, we calculated the Cronbach's alpha (Cronbach 1951), but this time for the results published for each sub-index. The result of 0.891 indicates that the variable grouping is valid because it is greater than 0.7 (Bland, Altman 1997).

Since the SPI constitutes a non-economic index to measure quality of life enhancement from multiple dimensions, in this study, the SPI was used as a dependent variable. To test this indicator's consistency as a measure of HD, we performed a correlation test between this index and the HDI using databases on the SPI and HDI for four annual periods (2014-2017), with information from 145 countries. The result obtained from the bivariate auto-correlation Pearson's test (1920) was 0.959 , with a confidence level of 99\%. Figure 1 shows the linearity of this relationship, which indicates that the SPI is a consistent measure of social progress as well as a suitable proxy of HD (Asandului, Iacobuta 2016; Efthymiou et al. 2016; Lo et al. 2017; Mattedi et al. 2015; Mayer et al. 2017).

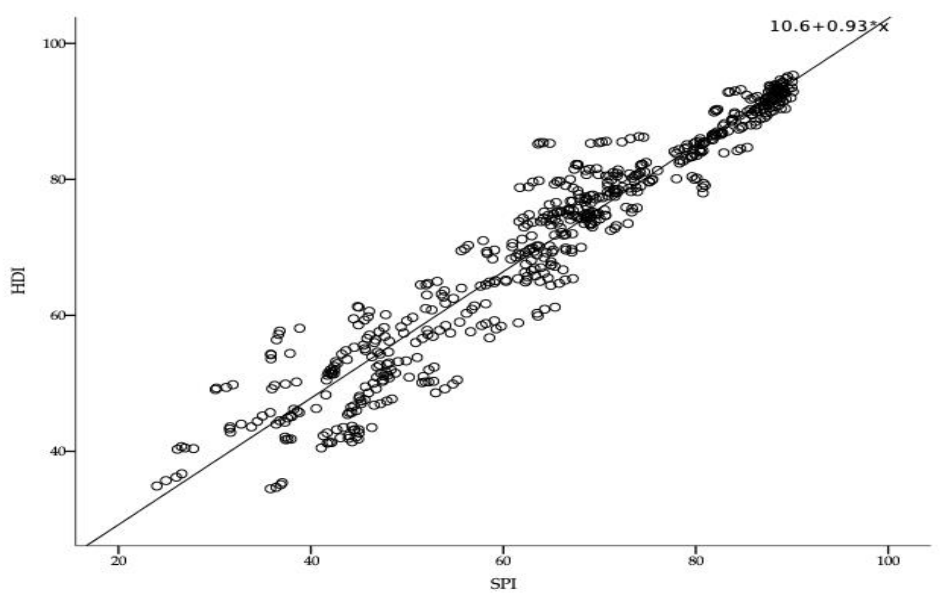

Fig.2. Relationship between the HDI and SPI

The SPI has been used in other studies that have attempted to explain the causes and effects of some of the processes of human interaction in improving quality of life (Asandului, Iacobuta 2016; Lo et al. 2017; Mattedi et al. 2015; Mayer et al. 2017). The analysis by Stanojević and Benčina (2019) identified the SPI as one of the most robust composite indexes for measuring quality of life because of the large number of indicators that measure how people are satisfying their needs while avoiding the use of GDP. The calculation of the SPI is supported by a complex theoretical foundation. The measure's major limitation is the short period it covers.

\subsubsection{Independent variables}

We divided the independent variables into two groups. The first measures innovative entrepreneurship and the second measures the institutional framework that encourages ICT usage in different countries. The variables in each group are detailed below. 


\section{ENTREPRENEURSHIP AND SUSTAINABILITY ISSUES}

ISSN 2345-0282 (online) http://jssidoi.org/jesi/

2019 Volume 7 Number 2 (Decembre)

http://doi.org/10.9770/jesi.2019.7.2(1)

\subsubsection{Entrepreneurship variable}

The entrepreneurship variable analyzed was the total entrepreneurial activity rate of innovation (TEAIN), measured as a percentage of all surveyed people involved in the total entrepreneurial activity rate. This type of entrepreneur is reported to provide new products or services for many of his or her customers and has few or no competitors. The TEAIN was obtained from the adult population survey published by the GEM administered in approximately 100 countries through stratified sampling by sex and age, considering the active population (people aged 18 to 64). The GEM usually provides 95\% confidence intervals for the estimates in its global reports (Bosma et al. 2017). Researchers have used the TEAIN to determine the relevance of innovation entrepreneurship to economic growth and development (Szabo, Herman 2013), the relationship between entrepreneurship and the business cycle (Koellinger, Thurik 2012), the influence of social progress on innovative entrepreneurship (Aparicio et al. 2016), and the relationship between leadership styles and innovative entrepreneurship (Van Hemmen et al. 2015).

\subsubsection{ICT usage variable}

The NRI measures a country's capacity to capitalize on ICT to increase competitiveness and welfare. It is structured into three categories including four sub-indexes (environment, readiness, usage, and impact); 10 pillars, distributed across the sub-indexes; and 53 indicators, distributed across the pillars. The Environment subindex is composed of laws and public policies affecting ICT implementation, innovation, and the development of entrepreneurial activities. The Readiness sub-index measures a society's willingness to use ICT. The Usage subindex measures the use of ICT in all sectors of society. Finally, the Impact (economic and social) sub-index is associated with ICT use (Baller et al. 2016). Appendix C presents the full structure of this index.

Detailed information on the method used to calculate the NRI is found in the Global Information Technology Report 2016 (World Economic Forum 2016b, p. xi): "The computation of the overall NRI score is based on successive aggregations of scores: individual indicators are aggregated to obtain pillar scores, which are then combined to obtain sub-index scores. Sub-index scores are in turn combined to produce a country's overall NRI score." As each aggregation step in the NRI applies equal weight, each sub-index has a weight of $25 \%$.

To evaluate the weighting scheme for the NRI, Maricic et al. (2019) applied the enhanced Scatter Search (eSS) metaheuristics technique to obtain a weighting scheme that would increase the stability of the composite indicator. The objective function is based on the relative contributions of the indicators, whereas the problem constraints rely on the bootstrap Composite I-Distance Indicator (CIDI) approach. The eSS-CIDI approach combines the exploration capability of eSS and data-driven constraints devised from the bootstrap CIDI. The results obtained by Maricic et al. (2019) initially suggested that the equal weightings for each sub-index of the NRI could change when the eSS-CIDI was applied. The proposed model does not, however, guarantee a more stable solution than the official estimation method, and thus it should not be changed. Maricic et al. (2019) suggested that the results of the proposed method can be interpreted as a means to verify the official weighting schema.

As an additional measure of the reliability of the NRI scales, we calculated the Cronbach's alpha for the published results for each of its 10 pillars. The result obtained was 0.946, indicating that the grouping of the variables is valid since it is greater than 0.7 (Bland, Altman 1997).

Given the importance of the NRI as a measurement for use and adoption of ICT in 151 countries, several researchers have used this index to demonstrate the relationship of ICT with different aspects of human life (Binsfeld et al. 2017; Gong et al. 2018; Huang et al. 2018; Indjikian, Siegel 2005; James 2012; Kottemann, 


\section{ENTREPRENEURSHIP AND SUSTAINABILITY ISSUES}

ISSN 2345-0282 (online) http://jssidoi.org/jesi/ 2019 Volume 7 Number 2 (Decembre) http://doi.org/10.9770/jesi.2019.7.2(1)

Boyer-Wright 2009; Larios-Hernández, Reyes-Mercado 2018; Ntemi, Mbamba 2016; Otioma et al. 2019; Samoilenko, Osei-Bryson 2018, 2019).

\subsubsection{Control variables}

Although the main goal of this study was to identify the relationships between the TEAIN and social progress and between ICT usage and social progress, other factors also enhance quality of life. We thus considered personal income to be a means to facilitate the functioning and broadening of capabilities (Drèze, Sen 2002). The variable used to measure income was GDP per capita, adjusted to purchasing power parity at international dollar prices; several researchers have used this variable to measure monetary income (Anand, Ravallion, 1993). The population of the countries included in the study was taken as another control variable, specifically those aged 15-64 years. Data on both GDP per capita and total population were obtained from the World Bank for 2016 (World Bank 2013).

\subsection{Method}

The availability of information to perform the empirical analysis determined the estimation method (Wooldridge 2009). One of the main limitations of this study is the absence of time series - sets that enable estimations reflecting the behavior of the variables over time. The sample in this study was constructed from four secondary information sources. The information on the SPI was obtained from the Social Progress Imperative, which, since 2014, has published the advances made in the social progress of 130 countries on average (Socialprogressindex.org 2018). The NRI was obtained from the World Economic Forum, which has published information from 2012 to 2016 on the performance of 151 countries in the use and adoption of ICT (World Economic Forum 2016a). The TEAIN was obtained from the GEM, which has been publishing information on the evolution of this type of entrepreneurship globally since 2011. The GEM samples vary each year (GEM 2018). Finally, the GDP data and total population aged 15-64 years were obtained from the World Bank, which has historical data of these indicators from 1960 to 2018 for approximately 217 countries (World Bank 2018).

Taking into account that the information comes from multiple sources, the sample size and period of study differ in each organization that generates the data. Therefore, to use the most recent information, the study period was selected according to the most recent year in which there was published information for all the variables. In this case, 2016 was the last period in which the NRI published. Similarly, the sample size was obtained by selecting those countries for which there is information on all the variables under study. For 2016, the organizations that process and publish the data coincided in the collection of information on 56 countries in different continents, as seen in the countries highlighted in blue in Map 1. Appendix D lists the countries analyzed. This sample provides evidence to reduce the gap in the relationship between ICT and HD because most studies to date have focused on countries in Africa and South America (Lwoga, Sangeda 2019; Thapa, Saebø 2014). 


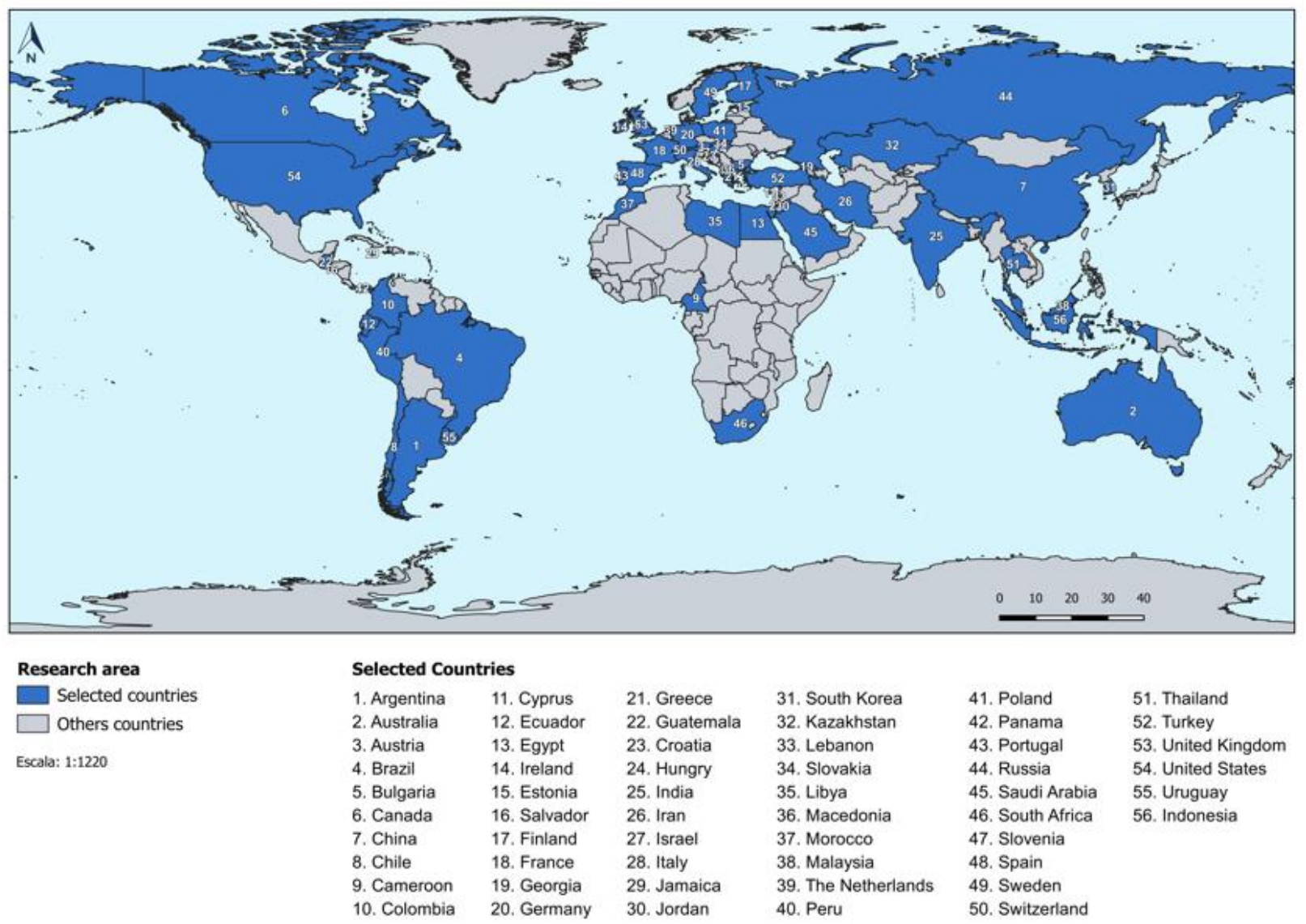

Map 1. Sample of the countries selected in this study

On the basis of the information available, the best technique for verifying the hypotheses proposed was ordinary least squares (OLS) in a cross-sectional regression. According to Urbano et al. (2019), OLS is the most commonly applied method for explaining the relationship between entrepreneurship, on the one hand, and institutions, development, and economic growth, on the other. The following models were created to test the hypotheses:

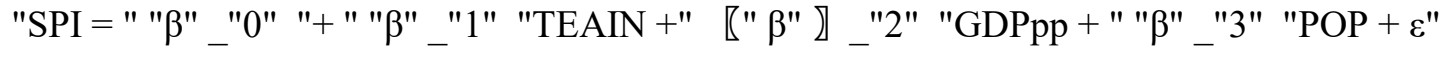

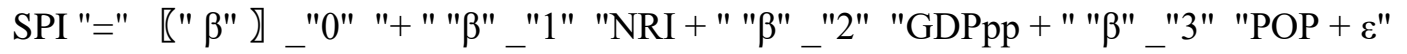

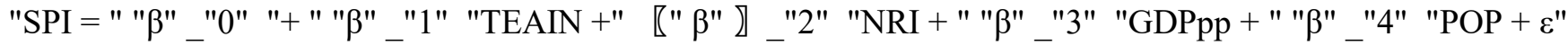

$$
\begin{aligned}
& \text { (3) }
\end{aligned}
$$

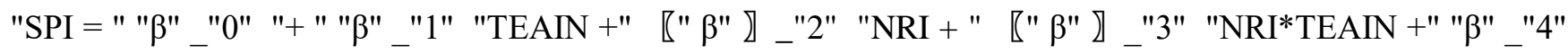

$$
\begin{aligned}
& \text { "GDPpp + " " } \beta " \text { " } 5 " \text { "POP + } \varepsilon "
\end{aligned}
$$


where the dependent variable is the SPI, the TEAIN represents innovative entrepreneurship, the NRI measures ICT usage and adoption in all sectors of society, GDPpp represents GDP per capita based on purchasing power parity, and POP represents the total population aged 15-64. The factors ranging from " $\beta$ " _" 0 " to 『" $\beta$ " \ are the estimated coefficients of each variable and " $\varepsilon$ " represents unobserved scalar random variables. In all the models, GDPpp and POP were converted into natural logarithms to facilitate the interpretation of the results. The percentage change in the independent variable thus causes a percentage change in the dependent variable, expressed in the respective coefficient (Wooldridge 2009). In Model (4), NRI $\times$ TEAIN represents the interaction between innovative entrepreneurship and ICT as the moderating variable.

Models (1) and (2) verify H1 and H2, respectively. Models (3) and (4) were built to verify H3; this is especially the case for Model (4), represented in Figure 3, which is an adaptation of Baron and Kenny's (1986) model. This figure has three causal paths oriented toward the outcome variable (SPI): the effect of innovative entrepreneurship as a predictor (Path a), the effect of ICT usage as a moderator (Path b), and the interaction or product of the two (Path c). according to Baron and Kenny (1986), "The moderator hypothesis is supported if the interaction (Path c) is significant" (p. 1174).

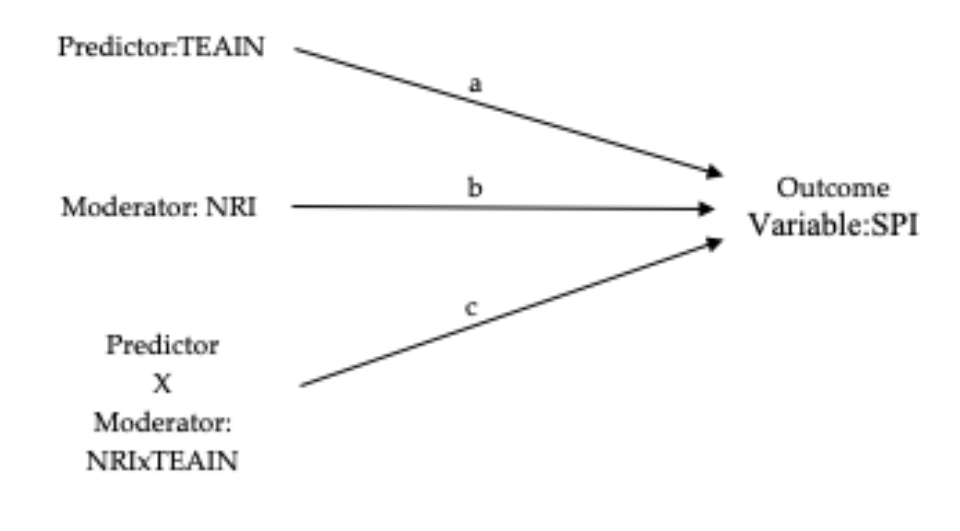

Fig.3. ICT as a moderator of the effect of innovative entrepreneurship on social progress. Based on Baron and Kenny's (1986) moderator model

The moderator can create multicollinearity problems since it would normally be correlated with the independent variables of which it is composed. Therefore, to control for the multicollinearity in Model (4), we used the deviation score approach following Cohen et al. (2014) by centering the data; we transformed the data into deviation scores, with means equal to zero.

\section{Results}

Table 3 summarizes the descriptive statistics of the variables used. The maximum and minimum values show no bias in sample selection due to the heterogeneity of the countries studied based on their levels of entrepreneurship, ICT adoption, and social progress. As Table 3 shows, the results of the bivariate correlations are consistent with the three hypotheses. These results provide initial evidence to test these three hypotheses. We found a positive and significant correlation between social progress and the TEAIN and a positive and significant correlation between social progress and ICT usage (NRI). 


\section{ENTREPRENEURSHIP AND SUSTAINABILITY ISSUES}

ISSN 2345-0282 (online) http://jssidoi.org/jesi/ 2019 Volume 7 Number 2 (Decembre) http://doi.org/10.9770/jesi.2019.7.2(1)

Table 3. Descriptive statistics and correlation matrix

\begin{tabular}{|c|c|c|c|c|c|c|c|c|c|c|}
\hline No. & Variable & Mean & SD & Min. & Max. & 1 & 2 & 3 & 4 & 5 \\
\hline 1 & SPI & 76.049 & 9.979 & 48.55 & 90.55 & 1 & & & \\
\hline 2 & TEAIN & 26.064 & 10.594 & 3.5 & 58.7 & $\begin{array}{c}0.426 \\
* * *\end{array}$ & 1 & & \\
\hline 3 & NRI & 65.485 & 10.389 & 42.602 & 85.089 & $\begin{array}{c}0.8498 \\
* * *\end{array}$ & $\begin{array}{c}0.383 \\
* * *\end{array}$ & 1 & \\
\hline 4 & $\operatorname{lnGDPppp}$ & 9.958 & 0.661 & 8.117 & 11.047 & $\begin{array}{c}0.8533 \\
* * *\end{array}$ & $\begin{array}{c}0.369 \\
* * *\end{array}$ & $\begin{array}{c}0.8672 \\
* * *\end{array}$ & $\begin{array}{c}1 \\
* * \\
\end{array}$ \\
\hline 5 & $\begin{array}{c}\text { lnPOP } \\
(15-64)\end{array}$ & 16.422 & 1.597 & 13.616 & 20.718 & $\begin{array}{c}-0.286 \\
-0.115\end{array}$ & $\begin{array}{c}-0.109 \\
-0.107\end{array}$ & 1 \\
\hline
\end{tabular}

Note: $* * * \mathrm{p}<0.01 ; * * \mathrm{p}<0.05$. lnGDPppp represents GDPppp converted into natural logarithms and lnPOP represents POP converted into natural logarithms.

Table 4 summarizes the results of the three regression analyses conducted using OLS. The robustness tests for the models were performed following the assumptions of Gauss Markov as a mechanism to validate this analysis technique (Wooldridge 2009). In all the models, multicollinearity and heteroscedasticity were rejected; similarly, their correct specification was verified. This set of estimations indicates that the independent variables significantly explain social progress. The results for each estimation are discussed below.

Table 4. Regression analysis

\begin{tabular}{|c|c|c|c|c|}
\hline Variable & \multicolumn{4}{|c|}{ SPI } \\
\hline & $\begin{array}{c}\text { Model } \\
(1)\end{array}$ & Model (2) & $\begin{array}{c}\text { Model } \\
(3)\end{array}$ & $\begin{array}{c}\text { Model } \\
(4)\end{array}$ \\
\hline TEAIN & $0.134 * *$ & & $0.1073 *$ & $0.146 * *$ \\
\hline & 0.660 & & 0.060 & 0.065 \\
\hline NRI & & $0.4142 * * *$ & $\begin{array}{c}0.385 \\
* * *\end{array}$ & $\begin{array}{c}0.317 \\
* * *\end{array}$ \\
\hline & & 0.115 & 0.114 & 0.126 \\
\hline NRI×TEAIN & & & & $0.134 *$ \\
\hline & & & & 0.075 \\
\hline GDPppp & 11.788 & $6.942 * * *$ & 6.698 & 0.487 \\
& $* * *$ & & $* * *$ & $* * *$ \\
\hline & 1.047 & 1.819 & 1.789 & 0.118 \\
\hline POP (15-64) & $-1.111 * *$ & -1.189 & -1.094 & -0.181 \\
& & $* * *$ & $* * *$ & $* * *$ \\
\hline & 0.409 & 0.377 & 0.374 & 0.058 \\
\hline
\end{tabular}

Note: $* * * \mathrm{p}<0.01 ; * * \mathrm{p}<0.05$, and $* \mathrm{p}<0.1$

Model (1) indicates that innovative entrepreneurship has a positive and significant relationship with social progress, which supports H1. Following the conceptualization of Gries and Naudé (2011), innovative entrepreneurship is an effective functioning because it satisfies economic needs as well as needs of selffulfillment. From Sen's (2005) perspective, this type of entrepreneurship enables people to do what they desire and then become who they want to be.

Model (2) shows that the variable measuring a country's capacity to use ICT to increase competitiveness and welfare has a positive and significant relationship with social progress, which supports $\mathrm{H} 2$. Similarly, this result is consistent with the proposed theoretical approach, which adds evidence to prior studies that have attempted to explain ICT use as a tool that facilitates functioning and that may enable people to achieve their goals (Andersson, Hatakka 2013; European Commission 2015; International Telecommunication Union \& United 


\section{ENTREPRENEURSHIP AND SUSTAINABILITY ISSUES}

ISSN 2345-0282 (online) http://jssidoi.org/jesi/ 2019 Volume 7 Number 2 (Decembre) http://doi.org/10.9770/jesi.2019.7.2(1)

Nations 2005; Jurado-González, Gómez-Barroso 2016; Kleine 2013; Oosterlaken 2012, 2014; Poveda, Roberts 2018; Rifkin 2014; Sen 2010; Thapa, Saebø 2014; Walsham 2017; World Economic Forum 2016b; Zheng et al. 2018).

The results obtained about the positive relationship between the NRI and SPI are supported by studies demonstrating that ICT facilitates people's lives, regardless of their socioeconomic status, as well as their access to basic goods and services, thus expanding capabilities and opportunities (Rifkin 2014). According to Sen (2010), ICT fundamentally helps establish human interactions in all social spheres, regardless of the economic paradigm or philosophical thinking followed. ICT is used by the most rudimentary to the most developed economies to facilitate exchanges of goods and services. The Information Society, especially open Internet access, is enabling the expansion of the collaborative economy, aiding a paradigm shift in the exchange of goods and services and in turn improving the quality of people's lives and the implementation of sustainable development theories. Collaborative economy platforms and open access to codes and data found on the Internet encourage highly innovative scientific development (Ferrer 2009)

In Model (3), both the independent variables (TEAIN and NRI) were added, increasing the explained variance of the SPI. However, the results of Model (4) are more suitable for testing H3 because it indicates that the interaction between innovative entrepreneurship and ICT has a positive and significant effect on social progress. This interaction increases the explained variance of the SPI with respect to the other models. H3 is thus validated (Baron, Kenny 1986). As a robustness test of the results of Model (4), we apply the highest order unconditional interaction (Hayes 2015; Hayes, Matthes 2009), finding that the increase in the explained variance of the SPI, originated by the product of NRI×TEAIN, is significant at $91.9 \%$ confidence levels.

The estimation of Model (4) also tests the robustness of the proposed empirical analysis. All the variables included in this model are significant and have a positive (with the exception of the total population) relationship with social progress. The negative coefficient of the population variable with social progress can be associated with two factors: the unequal distribution of resources globally and scarcity of resources influencing quality of life.

The four estimations show that GDP per capita has a positive and significant relationship with social progress. These results are consistent with the CA on the importance of monetary income as a resource for broadening capabilities. According to Sen and Drèze (2002), understanding development within the CA does not mean denying the significance of economic growth or technological progress as tools that encourage HD. The effectiveness of economic growth and ICT should be evaluated according to the extent to which they broaden capabilities.

The results of Model (4) concur with the approach proposed by the World Economic Forum (2016b): properly channeled ICT can generate economic and social gains and increased ICT usage by firms can constitute a key element for development. This finding suggests that governments should encourage firms to adopt and use these technologies.

The Internet enables access to technical and specialized knowledge. The best universities in the world have a range of open courses through platforms such as Coursera and edX, which allow people to access knowledge. The development of innovations with a technological component has been promoted by open access to specialized research and open source software (World Economic Forum 2015). Similarly, virtual platforms of a collaborative economy foster activities from satisfying needs for food and leisure to obtaining financial capital to boost entrepreneurial activities (European Commission 2016; World Economic Forum 2015). 


\section{ENTREPRENEURSHIP AND SUSTAINABILITY ISSUES}

ISSN 2345-0282 (online) http://jssidoi.org/jesi/ 2019 Volume 7 Number 2 (Decembre) http://doi.org/10.9770/jesi.2019.7.2(1)

The use of the Internet as a platform for business enables the entrepreneur to overcome financing barriers through crowdfunding (Park 2012). Crowdfunding platforms worldwide raised USD $\$ 16.2$ billion in 2014, an increase of $167 \%$ over 2013. Of the total collected in $2014,41.3 \%$ (equivalent to USD $\$ 6.7$ billion) corresponded to investments in business and entrepreneurship (Crowdfund Insider 2019). The most visible impact of Internet usage on entrepreneurship activities is associated with creating new market segments emerging through online start-ups, targeting $45.9 \%$ of Internet users worldwide. Start-ups have lower operational costs because the network helps distribute their products or services. The largest of these companies are ranked among the most profitable in the world: Google, Facebook, Amazon, and eBay (Baller et al. 2016; World Economic Forum 2015).

\section{Conclusions}

Research on the effects of entrepreneurship and ICT has focused on establishing the impacts on economic growth, productivity, and employment. However, this study presents new evidence of the link between innovation entrepreneurship and ICT and their influence on HD using the CA as a theoretical frame of reference. The CA helps us understand how a human activity or resource can enhance quality of life.

First, our analysis of innovative entrepreneurship, which is equivalent to a functioning as it represents a human activity, enables people to be what they wish - the innovative entrepreneur performs this activity spontaneously, employing his or her personal conversion factors, resources, and capabilities. This action is valued positively because it contributes to satisfying a person's individual needs and encourages the expansion of his or her capabilities. Taking the SPI as a measure of HD, we confirm that innovation entrepreneurship positively influences HD, at least in the dimensions measured by the SPI: satisfaction of basic needs, foundations of wellbeing, and opportunity.

Second, ICT is a crucial resource that may expand capabilities and functioning for people to lead the life they desire. On this, we provide new evidence of the influence of ICT on HD, as increases in ICT usage and adoption, measured by the NRI, raise HD, measured by the SPI.

Finally, we provide new evidence that ICT moderates the effects of innovative entrepreneurship on social progress. In this sense, according to the estimation results of Model (4), we conclude that ICT boosts the positive effect of innovative entrepreneurship on social progress. This affirmation confirms the UN's conclusion that the positive impact of ICT on HD is greater if it is related directly to a specific human activity.

The main limitation facing this study is the scarcity of secondary information that would allow us to adopt causality statistical techniques such as Granger as well as estimations with other techniques related to time series such as panel data. Our results are thus only an approximation of the influence of entrepreneurship and ICT on HD.

From a practical standpoint, this study's results could be useful in the design of policies supporting opportunity entrepreneurship, especially for innovation, because necessity entrepreneurship restricts human agency and its impact on people's quality of life is questionable. Therefore, it is necessary to reduce subsistence selfemployment rates by expanding remunerated job offers. To promote innovative entrepreneurship, public programs could support nascent entrepreneurs to adopt and use ICT because this helps reduce both production and distribution costs. Further, ICT encourages market expansion online, generating opportunities for both entrepreneurs and customers to improve their quality of life.

In addition, strengthening and creating public programs that encourage an institutional framework (political, normative, and economic) for the adoption and use of ICT, especially the Internet, is recommended because these 
tools make it easier for people to improve their quality of life. In many countries, programs exist to support the adoption and use of ICT. However, there is a growing trend, in both developed and developing countries, to establish barriers to Internet access, which could threaten the fundamental right to freedom of expression and weaken the Information Society, which favors the expansion of capabilities so that people can lead the life they really want. It is therefore essential that public policies in each country and international agreements continue to defend free and secure access to the Internet as the main means of global communication and information provision.

Finally, concerning the methodological limitations, future research should continue to provide information on the impact of entrepreneurship and ICT on HD. To this end, multidimensional synthetic indexes about HD could be created with information on cities or regions to determine its relationship with the creation of new firms in specific territories.

\section{Appendix A}

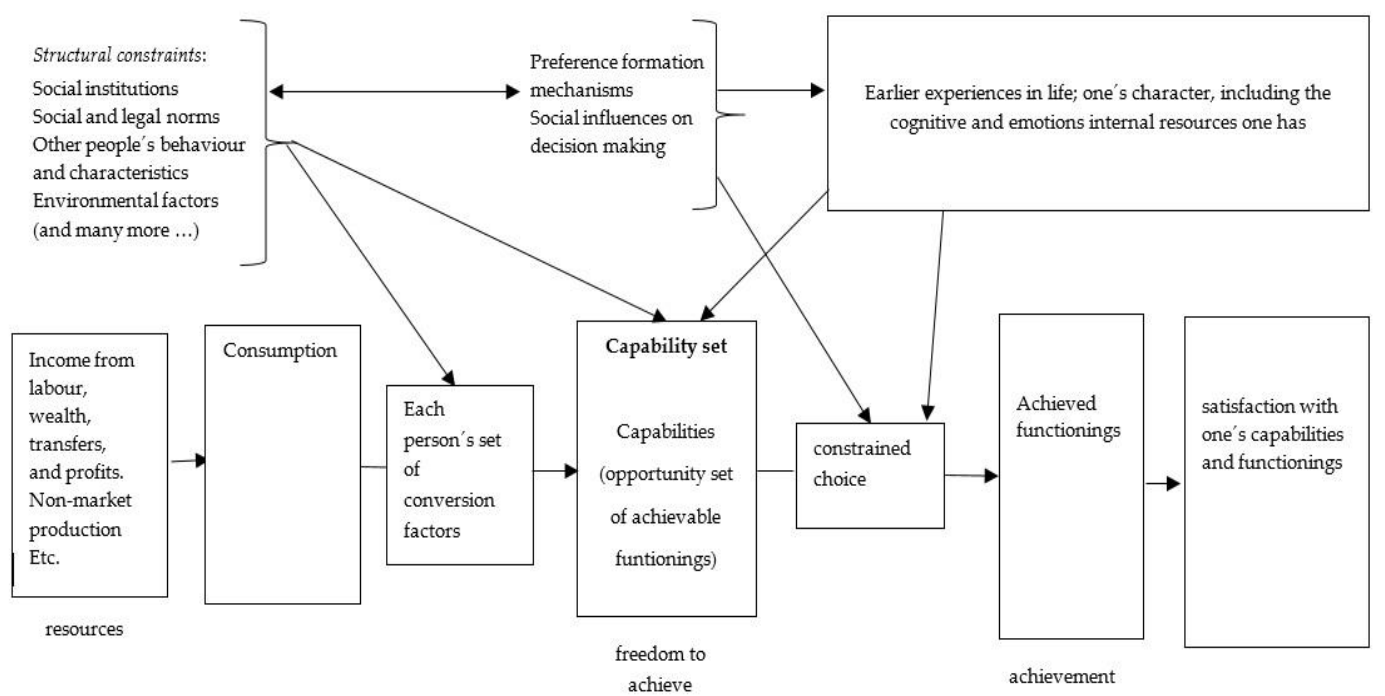

Fig.A1. Stylized visualization of the core concepts of capability theories

Source: Robeyns (2017)

\section{Appendix B}

Table A1. Structure of the SPI

\begin{tabular}{|c|c|c|}
\hline Basic Human Needs & Nutrition and basic medical care & $\begin{array}{c}\text { Undernourishment } \\
\text { Depth of the food deficit } \\
\text { Maternal mortality rate } \\
\text { Child mortality rate }\end{array}$ \\
& Deaths from infectious diseases \\
\cline { 2 - 3 } & Water and sanitation & $\begin{array}{c}\text { Access to piped water } \\
\text { Shelter }\end{array}$ \\
\cline { 2 - 3 } & $\begin{array}{c}\text { Rural access to improved water sources } \\
\text { Access to improved sanitation facilities }\end{array}$ & $\begin{array}{c}\text { Availability of affordable housing } \\
\text { Access to electricity } \\
\text { Quality of electricity supply }\end{array}$ \\
\hline
\end{tabular}


ENTREPRENEURSHIP AND SUSTAINABILITY ISSUES

ISSN 2345-0282 (online) http://jssidoi.org/jesi/

2019 Volume 7 Number 2 (Decembre)

http://doi.org/10.9770/jesi.2019.7.2(1)

\begin{tabular}{|c|c|c|}
\hline & & Household air pollution attributable deaths \\
\hline & Personal safety & $\begin{array}{c}\text { Homicide rate } \\
\text { Level of violent crime } \\
\text { Perceived criminality } \\
\text { Political terror } \\
\text { Traffic deaths }\end{array}$ \\
\hline \multirow[t]{4}{*}{$\begin{array}{l}\text { Foundations of Well- } \\
\text { being }\end{array}$} & Access to basic knowledge & $\begin{array}{c}\text { Adult literacy rate } \\
\text { Primary school enrollment } \\
\text { Secondary school enrollment } \\
\text { Gender parity in secondary enrollment }\end{array}$ \\
\hline & Health and wellness & $\begin{array}{c}\text { Life expectancy at } 60 \\
\text { Premature deaths from noncommunicable } \\
\text { diseases } \\
\text { Suicide rate } \\
\end{array}$ \\
\hline & $\begin{array}{l}\text { Access to information and } \\
\text { communications }\end{array}$ & $\begin{array}{c}\text { Call phone subscriptions } \\
\text { Internet users } \\
\text { Press Freedom Index } \\
\end{array}$ \\
\hline & Environmental quality & $\begin{array}{c}\text { Wastewater treatment } \\
\text { Outdoor air pollution attributable deaths } \\
\text { Biodiversity and habitat } \\
\text { Greenhouse gas emissions } \\
\end{array}$ \\
\hline \multirow[t]{4}{*}{ Opportunity } & Personal rights & $\begin{array}{l}\text { Political rights } \\
\text { Freedom of expression } \\
\text { Freedom of assembly } \\
\text { Private property rights }\end{array}$ \\
\hline & Personal freedom and choice & $\begin{array}{c}\text { Freedom over life choices } \\
\text { Freedom of religion } \\
\text { Early marriage } \\
\text { Satisfied demand for contraception } \\
\text { Corruption }\end{array}$ \\
\hline & Tolerance and inclusion & $\begin{array}{c}\text { Tolerance for immigrants } \\
\text { Tolerance for homosexuals } \\
\text { Discrimination and violence against minorities } \\
\text { Religious tolerance } \\
\text { Community safety net }\end{array}$ \\
\hline & Access to advanced education & $\begin{array}{c}\text { Years of tertiary schooling } \\
\text { Women's average years in school } \\
\text { Inequality in the attainment of education } \\
\text { Globally ranked universities } \\
\text { Percentage of tertiary students enrolled in globally ranked } \\
\text { universities }\end{array}$ \\
\hline
\end{tabular}

Source: Methodology Report, SPI (Stern et al. 2014).

\section{Appendix C}

Table A2. ICT usage sub-index of the NRI

\begin{tabular}{|c|c|c|}
\hline Subindex & Pillar & Indicators \\
\hline & & $\begin{array}{c}\text { Political and } \\
\text { regulatory } \\
\text { environment }\end{array}$ \\
& & Effectiveness of law-making bodies \\
& Laws relating to ICT \\
& Judicial independence \\
& Efficiency of legal framework in settling disputes \\
& Efficiency of legal framework in challenging regulations \\
& Intellectual property protection \\
& Software piracy rate \\
& Number of procedures to enforce a contract \\
\hline
\end{tabular}


ENTREPRENEURSHIP AND SUSTAINABILITY ISSUES

ISSN 2345-0282 (online) http://jssidoi.org/jesi/ 2019 Volume 7 Number 2 (Decembre) http://doi.org/10.9770/jesi.2019.7.2(1)

\begin{tabular}{|c|c|c|}
\hline & & Time required to enforce a contract \\
\hline & $\begin{array}{l}\text { Business and } \\
\text { innovation } \\
\text { environment }\end{array}$ & $\begin{array}{c}\text { Availability of latest technologies } \\
\text { Venture capital availability } \\
\text { Total tax rate } \\
\text { Time required to start a business } \\
\text { Number of procedures required to start a business } \\
\text { Intensity of local competition } \\
\text { Tertiary education enrollment rate } \\
\text { Quality of management schools } \\
\text { Government procurement of advanced technology products }\end{array}$ \\
\hline \multirow{3}{*}{ Readiness } & Infrastructure & $\begin{array}{c}\text { Electricity production } \\
\text { Cell network coverage rate } \\
\text { International Internet bandwidth } \\
\text { Secure Internet servers }\end{array}$ \\
\hline & Affordability & $\begin{array}{c}\text { Prepaid cellular tariffs } \\
\text { Fixed broadband Internet tariffs } \\
\text { Internet and telephony sectors competition index }\end{array}$ \\
\hline & Skills & $\begin{array}{c}\text { Quality of education system } \\
\text { Quality of math and science education } \\
\text { Secondary education enrollment rate } \\
\text { Adult literacy rate }\end{array}$ \\
\hline \multirow{3}{*}{ Usage } & Individual usage & $\begin{array}{l}\text { Subscriptions to cell phones } \\
\text { Percentage of individuals using Internet } \\
\text { Households with personal computer } \\
\text { Households with Internet Access } \\
\text { Fixed broadband Internet subscriptions } \\
\text { Cell broadband Internet subscriptions } \\
\text { Use of virtual social networks }\end{array}$ \\
\hline & Business usage & $\begin{array}{c}\text { Firm-level technology absorption } \\
\text { Capacity for innovation } \\
\text { Patent applications } \\
\text { ICT use for business-to-business transactions } \\
\text { Business-to-consumer Internet use } \\
\text { Extent of staff training }\end{array}$ \\
\hline & $\begin{array}{c}\text { Government } \\
\text { usage }\end{array}$ & $\begin{array}{l}\text { Importance of ICT for government vision } \\
\text { Government Online Service Index } \\
\text { Government success in ICT promotion }\end{array}$ \\
\hline \multirow{2}{*}{ Impact } & $\begin{array}{l}\text { Economic } \\
\text { impacts }\end{array}$ & $\begin{array}{l}\text { Impact of ICT on business models } \\
\text { ICT PCT patent applications per million population } \\
\text { Impact of ICT on organizational models } \\
\text { Knowledge-intensive jobs, \% workforce }\end{array}$ \\
\hline & Social impacts & $\begin{array}{l}\text { Impact of ICTs on access to basic services } \\
\text { Internet access in schools } \\
\text { ICT use and government efficiency } \\
\text { E-participation Index }\end{array}$ \\
\hline
\end{tabular}

Source: The Global Information Technology Report (World Economic Forum 2016b). 


\section{ENTREPRENEURSHIP AND SUSTAINABILITY ISSUES}

ISSN 2345-0282 (online) http://jssidoi.org/jesi/ 2019 Volume 7 Number 2 (Decembre) http://doi.org/10.9770/jesi.2019.7.2(1)

\section{Appendix D}

Table A3. Countries analyzed in this study with information from the GEM; World Economic Forum, Social Progress Imperative, and World Bank, 2016.

\begin{tabular}{|c|c|c|}
\hline \multicolumn{3}{|c|}{ Country } \\
\hline Argentina & Germany & The Netherlands \\
\hline Australia & Greece & Peru \\
\hline Austria & Guatemala & Poland \\
\hline Brazil & Hungry & Portugal \\
\hline Bulgaria & India & Russia \\
\hline Cameroon & Indonesia & Saudi Arabia \\
\hline Canada & Iran & Slovakia \\
\hline Chile & Ireland & Slovenia \\
\hline China & Israel & South Korea \\
\hline Colombia & Italy & South Africa \\
\hline Croatia & Jamaica & Spain \\
\hline Cyprus & Jordan & Sweden \\
\hline Ecuador & Kazakhstan & Switzerland \\
\hline Egypt & Libya & Thailand \\
\hline Salvador & Lebanon & Turkey \\
\hline Estonia & Macedonia & United Kingdom \\
\hline Finland & Malaysia & United States \\
\hline France & Morocco & Uruguay \\
\hline Georgia & Panama & \\
\hline
\end{tabular}

\section{References}

Acs, Z. J., Audretsch, D. B., Braunerhjelm, P., \& Carlsson, B. 2012. Growth and entrepreneurship. Small Business Economics 39(2): 289300. https://doi.org/10.1007/s11187-010-9307-2

Acs, Z. J., \& Storey, D. 2004. Introduction: Entrepreneurship and economic development. Regional Studies 38(8): 871-877. https://doi.org/10.1080/0034340042000280901

Acs, Z. J., \& Szerb, L. 2007. Entrepreneurship, economic growth and public policy. Small Business Economics 28(2-3): 109-122. https://doi.org/10.1007/s11187-006-9012-3

Alderete, M. V. 2017. Mobile broadband: A key enabling technology for entrepreneurship? Journal of Small Business Management 55(2): 254-269. https://doi.org/10.1111/jsbm.12314

Alkire, S. 2005. Briefing note capability and functionings: Definition \& justification. Human Development and Capability Association, 1- 


\section{ENTREPRENEURSHIP AND SUSTAINABILITY ISSUES}

ISSN 2345-0282 (online) http://jssidoi.org/jesi/ 2019 Volume 7 Number 2 (Decembre) http://doi.org/10.9770/jesi.2019.7.2(1)
6.
Retrieved
from
$\% 20$ Capability $\% 20$ Functioning\%20Briefing\%20Note.pdf

http://terpconnect.umd.edu/ dcrocker/Courses/Docs/Alkire\%20-

Alkire, S. 2008. The capability approach to the quality of life. Background Report Prepared for the Commission on the Measurement of Economic Performance and Social Progress.

Alkire, S., \& Foster, J. 2011. Counting and multidimensional poverty measurement. Journal of Public Economics 95(7-8): 476-487. https://doi.org/10.1016/j.jpubeco.2010.11.006

Anand, P., Hunter, G., Carter, I., Dowding, K., Guala, F., \& Van Hees, M. 2009. The development of capability indicators. Journal of Human Development and Capabilities 10(1): 125-152. https://doi.org/10.1080/14649880802675366

Anand, S., \& Ravallion, M. 1993. Human development in poor countries: On the role of private incomes and public services. Journal of Economic Perspectives 7(1): 133-150. https://pubs.aeaweb.org/doi/pdfplus/10.1257/jep.7.1.133

Anand, S., \& Sen, A. 2000. Human development and economic sustainability. World Development 28(12): 2029-2049. https://doi.org/10.1016/S0305-750X(00)00071-1

Andersson, A., \& Hatakka, M. 2013. What are we doing? Theories used in ICT4D research. IFIP Working Group 9.4. 12th International Conference on Social Implications of Computers in Developing Countries, May 19-22, 2013, Ocho Rios, Jamaica, $282-300$. Retrieved from http://www.diva-portal.org/smash/record.jsf?pid=diva2\%3A624715\&dswid=-3065

Anwar, M., \& Johanson, G. 2014. Mobile phones and religion: The case of women micro-entrepreneurs in a religious community in Indonesia. In Clarke, M., \& Tittensor, D. (Eds.). Islam and development: Exploring the invisible aid economy. Abingdon-onThames: Routledge, 135-152. https://doi.org/10.4324/9781315589893-13

Anwar, M., \& Johanson, G. 2015. Mobile phones and the well-being of blind micro-entrepreneurs in Indonesia. Electronic Journal of Information Systems in Developing Countries 67(1): 1-18. https://doi.org/10.1002/j.1681-4835.2015.tb00481.x

Aparicio, S., Urbano, D., \& Audretsch, D. 2016. Institutional factors, opportunity entrepreneurship and economic growth: Panel data evidence. Technological Forecasting and Social Change 102: 45-61. https://doi.org/10.1016/j.techfore.2015.04.006

Asandului, L., \& Iacobuta, A. 2016. Modelling economic growth based on economic freedom and social progress. Ecsdev.Org. Retrieved from http://ecsdev.org/ojs/index.php/ejsd/article/view/348

Atkinson, A. B. 2002. Social indicators: The EU and social inclusion. Oxford: Oxford University Press.

Audretsch, D. B. 2007. Entrepreneurship capital and economic growth. Oxford Review of Economic Policy 23(1): 63-78. https://doi.org/10.1093/oxrep/grm001

Audretsch, D. B. 2012. Entrepreneurship research. Management Decision 50(5): 755-764. https://doi.org/10.1108/00251741211227384

Audretsch, D. B., Bönte, W., \& Keilbach, M. 2008. Entrepreneurship capital and its impact on knowledge diffusion and economic performance. Journal of Business Venturing 23(6): 687-698. https://doi.org/10.1016/J.JBUSVENT.2008.01.006

Baller, S., Dutta, S., \& Lanvin, B. 2016. The Global Information Technology Report 2016 Innovating in the Digital Economy. (B. Lanvin \& INSEAD, Eds.). Geneva. Retrieved from http://www.aciem.org/home/images/Prensa/Newsletter/PDF_Notas_Prensa_Int_Gen_07_Jul_2016.pdf

Baron, R. M., \& Kenny, D. A. 1986. The moderator-mediator variable distinction in social psychological research: Conceptual, strategic, and statistical considerations. Journal of Personality and Social Psychology 51(6): 1173-1182. https://doi.org/10.1037/0022$\underline{3514.51 .6 .1173}$

Baumol, W. J. 1990. Entrepreneurship: Productive, unproductive, and destructive. Journal of Political Economy 98(5, 1): 893-921. https://doi.org/10.1086/261712

Baumol, W. J. 1993. Entrepreneurship, management, and the structure of payoffs. Cambridge, MA: MIT Press.

Binder, M., \& Coad, A. 2016. How satisfied are the self-employed? A life domain view. Journal of Happiness Studies 17(4): 1409-1433. https://doi.org/10.1007/s10902-015-9650-8 


\section{ENTREPRENEURSHIP AND SUSTAINABILITY ISSUES}

ISSN 2345-0282 (online) http://jssidoi.org/jesi/ 2019 Volume 7 Number 2 (Decembre) http://doi.org/10.9770/jesi.2019.7.2(1)

Binsfeld, N., Whalley, J., \& Pugalis, L. 2017. Playing the game: Explaining how Luxembourg has responded to the Networked Readiness Index. Digital Policy, Regulation and Governance 19(4): 269-286. https://doi.org/10.1108/DPRG-02-2017-0008

Birch, D. L. (1981). Who creates jobs? The Public Interest 65(Fall): $12 . \quad$ Retrieved from https://search.proquest.com/docview/1298113819/fulltextPDF/E178F0F99D3143C6PQ/1 ?accountid=14542

Bland, J. M., \& Altman, D. G. (1997). Cronbach’s alpha. British Medical Journal 314, 572. https://doi.org/10.1136/BMJ.314.7080.572

Block, J. H., Kohn, K., Miller, D., \& Ullrich, K. 2015. Necessity entrepreneurship and competitive strategy. Small Business Economics 44(1): 37-54. https://doi.org/10.1007/s11187-014-9589-x

Bosma, N., Litovsky, Y., Coduras, A., Seaman, J., Francis, J., Carmona, J., \& Wright, F. 2017. Gem Manual, 2012.

Bourguignon, F., \& Chakravarty, S. R. 2003. The measurement of multidimensional poverty. Journal of Economic Inequality 1(1). Retrieved from http://www.ophi.org.uk/wp-content/uploads/Bourgignon-Chakravarty-2003.pdf

Carree, M., Van Stel, A., Thurik, R., \& Wennekers, S. 2007. The relationship between economic development and business ownership revisited. Entrepreneurship \& Regional Development 19(3): 281-291. https://doi.org/10.1080/08985620701296318

Chambers, R. 1983. Rural development: Putting the last first. New York: Wiley.

Chen, F. W., Fu, L. W., Wang, K., Tsai, S. B., \& Su, C. H. 2018. The influence of entrepreneurship and social networks on economic growth: From a sustainable innovation perspective. Sustainability 10(7): 2510. https://doi.org/10.14202/vetworld.2017.711-715_old

Cohen, P., West, S. G., \& Aiken, L. S. 2014. Applied multiple regression/correlation analysis for the behavioral sciences. Hove, UK: Psychology Press. https://doi.org/10.4324/9781410606266

Coulibaly, S. K., Erbao, C., \& Metuge Mekongcho, T. 2018. Economic globalization, entrepreneurship, and development. Technological Forecasting and Social Change 127: 271-280. https://doi.org/10.1016/J.TECHFORE.2017.09.028

Cronbach, L. J. 1951. Coefficient alpha and the internal structure of tests. Psychometrika 16(3): 297-334. https://doi.org/10.1007/BF02310555

Crowdfund Insider. 2019, January 10. Massolution posts research findings: Crowdfunding market grows 167\% in 2014, Crowdfunding platforms raise $\$ 16.2$ billion. Retrieved from https://www.crowdfundinsider.com/2015/03/65302-massolution-posts-researchfindings-crowdfunding-market-grows-167-in-2014-crowdfunding-platforms-raise-16-2-billion/

Cuéllar-Gálvez, D., Aranda-Camacho, Y., \& Mosquera-Vásquez, T. 2018. A model to promote sustainable social change based on the scaling up of a high-impact technical innovation. Sustainability 10(12): 4532. https://doi.org/10.3390/su10124532

Demartini, P. 2018. Innovative female-led startups. Do women in business underperform? Administrative Sciences 8(4): 70. https://doi.org/10.3390/admsci8040070

Drèze, J., \& Sen, A. 199). Hunger and public action. Oxford: Oxford University Press. https://doi.org/10.1093/0198283652.001.0001

Drèze, J., \& Sen, A. 2002. India: Development and participation. Oxford: Oxford University Press.

Duncombe, R. 2003. Information technologies and international development (Vol. 3). Boston: MIT Press. Retrieved from https://itidjournal.org/index.php/itid/article/view/231

Efthymiou, L., Mavragani, A., \& Tsagarakis, K. 2016. Quantifying the effect of macroeconomic and social factors on illegal e-waste trade. International Journal of Environmental Research and Public Health 13(8): 789. https://doi.org/10.3390/ijerph13080789

European Commission. 2015. A Digital Single Market Strategy for Europe - Analysis and Evidence. Brussels. Retrieved from http://eurlex.europa.eu/legal-content/EN/TXT/PDF/?uri=CELEX:52015SC0100\&from=en

European Commission. 2016. The use of collaborative platforms Fieldwork. https://doi.org/10.2873/598782

Ferrer, E. 2009. ICT policy and perspectives of human development in Latin America: The Peruvian experience. Journal of Technology 


\section{ENTREPRENEURSHIP AND SUSTAINABILITY ISSUES}

ISSN 2345-0282 (online) http://jssidoi.org/jesi/ 2019 Volume 7 Number 2 (Decembre) http://doi.org/10.9770/jesi.2019.7.2(1)

Management \& Innovation 4(4): 161-170. https://doi.org/10.4067/S0718-27242009000400014

Frank, A. G. 1967. Capitalism and underdevelopment in Latin America. New York: NYU Press.

Fukuda-Parr, S. 2003. The human development paradigm: Operationalizing Sen's ideas on capabilities. Feminist Economics 9(2-3): 301317. https://doi.org/10.1080/1354570022000077980

General Assembly of the United Nations. 2002. Resolution Adopted by the General Assembly, 56/183 - World Summit on the Information Society 2002. Retrieved from https://www.itu.int/net/wsis/docs/background/resolutions/56_183_unga_2002.pdf

General Assembly of the United Nations. 2012. Resolution 20/8. The promotion, protection and enjoyment of human rights on the Internet 2012. Retrieved from https://digitallibrary.un.org/record/731540/files/A_HRC_RES_20_8-EN.pdf

General Assembly of the United Nations.2015. Resolution 70/125 Outcome document of the high-level meeting of the General Assembly on the overall review of the implementation of the outcomes of the World Summit on the Information Society 2015. Retrieved from http://unctad.org/en/PublicationsLibrary/ares70d125_en.pdf

GEM. 2018. Entrepreneurial behaviour and attitudes. Retrieved from https://www.gemconsortium.org/data/key-aps

Gnyawali, D., \& Fogel, D. 1994. Environments for entrepreneurship development: Key dimensions and research implications. Entrepreneurship: Theory \& Practice 18(4): 43-62. https://doi.org/10.1177/104225879401800403

Gong, J., Hong, Y., \& Zentner, A. 2018. Role of monetary incentives in the digital and physical inter-border labor flows. Journal of Management Information Systems, 35(3): 866-899. https://doi.org/10.1080/07421222.2018.1481661

Gries, T., \& Naudé, W. 2011. Entrepreneurship and human development: A capability approach. Journal of Public Economics 95(3): 216224. https://doi.org/10.1016/i.jpubeco.2010.11.008

Hamel, J.-Y. 2010. ICT4D and the human development and capabilities approach: the potentials of information and communication technology. Human Development Reports Research Paper, 37: 23. Retrieved from http://mpra.ub.uni-muenchen.de/25561/

Harbi, S. El., \& Grolleau, G. 2012. Does self-employment contribute to national happiness? Journal of Socio-Economics 41(5): 670-676. https://doi.org/10.1016/j.socec.2012.06.001

Hayes, A. F. 2015. An index and test of linear moderated mediation. Multivariate Behavioral Research 50(1): 1-22. https://doi.org/10.1080/00273171.2014.962683

Hayes, A. F., \& Matthes, J. 2009. Computational procedures for probing interactions in OLS and logistic regression: SPSS and SAS implementations. Behavior Research Methods 41(3): 924-936. https://doi.org/10.3758/BRM.41.3.924

Heeks, R. 2010. Do information and communication technologies (ICTs) contribute to development? Journal of International Development 22(5): 625-640. https://doi.org/10.1002/jid.1716

Hirai, T. 2017. The human development index and its evolution, in Hirai, T. (Ed.). The creation of the human development approach. Cham: Springer International Publishing, 73-121. https://doi.org/10.1007/978-3-319-51568-7_4

Huang, M., Jie, T., \& Huang, X. 2018. Study on digital technology in BRICS, in Zhao X., Li M., Huang M., \& Sokolov A. (Eds.). BRICS Innovative Competitiveness Report 2017. Research Series on the Chinese Dream and China's Development Path. Springer: Singapore, 221-240. https://doi.org/10.1007/978-981-10-8078-4_9

Indjikian, R., \& Siegel, D. S. 2005. The impact of investment in it on economic performance: Implications for developing countries. World Development 33(5): 681-700. https://doi.org/10.1016/J.WORLDDEV.2005.01.004

International Telecommunication Union. 2008. World Telecommunication/ICT Indicators. Retrieved from https://www.itu.int/en/ITUD/Statistics/Pages/publications/wtid.aspx

International Telecommunication Union \& United Nations. 2005. Cumbre Mundial sobre la Sociedad de la Información. Documentos Finales. Retrieved from www.itu.int/wsis

James, J. 2012. The ICT Development Index and the digital divide: How are they related? Technological Forecasting and Social Change 


\section{ENTREPRENEURSHIP AND SUSTAINABILITY ISSUES}

ISSN 2345-0282 (online) http://jssidoi.org/jesi/ 2019 Volume 7 Number 2 (Decembre) http://doi.org/10.9770/jesi.2019.7.2(1)

79(3): 587-594. https://doi.org/10.1016/J.TECHFORE.2011.08.010

Johnston, K. A., Jali, N., Kundaeli, F., \& Adeniran, T. 2015. ICTs for the broader development of South Africa: An analysis of the literature. The Electronic Journal of Information Systems in Developing Countries 70(1): 1-22. https://doi.org/10.1002/j.1681$\underline{4835.2015 . t b 00503 . x}$

Jones, C. I., \& Klenow, P. J. 2010. Beyond GDP? Welfare across countries and time. Human Development 106(9): 55. https://doi.org/10.1257/aer.20110236

Jurado-González, J., \& Gómez-Barroso, J. L. 2016. What became of the information society and development? Assessing the information society's relevance in the context of an economic crisis. Information Technology for Development 22(3): 436-463. https://doi.org/10.1080/02681102.2016.1155143

Kemal, A. A. 2019. ICTs and entrepreneurial development: A critical review through the livelihood lens. Retrieved from https://www.ukais.org/resources/Documents/ukais 2019 proceedings papers/paper_4.pdf

Kirzner, I. M. 1973. Competition and entrepreneurship. Chicago: The University of Chicago.

Kleine, D. 2010. ICT4what? Using the choice framework to operationalise the capability approach to development. Journal of International Development 22(5): 674-692. https://doi.org/10.1002/jid.1719

Kleine, D. 2013. Technologies of choice? ICTs, development, and the capabilities approach. Boston: MIT Press.

Klugman, J., Rodríguez, F., \& Choi, H. J. 2011. The HDI 2010: New controversies, old critiques. Journal of Economic Inequality 9(2): 249-288. https://doi.org/10.1007/s10888-011-9178-Z

Koellinger, P. D., \& Thurik, A. R. 2012. Entrepreneurship and the business cycle. Review of Economics and Statistics 94(4): 1143-1156. https://doi.org/10.1162/REST_a_00224

Kottemann, J. E., \& Boyer-Wright, K. M. 2009. Human resource development, domains of information technology use, and levels of economic prosperity. Information Technology for Development 15(1): 32-42. https://doi.org/10.1002/itdj.20114

Kuznets, S. 1955. Economic growth and income inequality. The American Economic Review 45(1): 1-28. Retrieved from http://www.jstor.org/stable/1811581

Landström, H., Harirchi, G., \& Åström, F. (2012). Entrepreneurship: Exploring the knowledge base. Research Policy 41(7): 1154-1181. https://doi.org/10.1016/j.respol.2012.03.009

Larios-Hernández, G. J., \& Reyes-Mercado, P. 2018. Market influencers for ICT advancement in small states: A comparative analysis. Information Technology for Development 24(3): 612-631. https://doi.org/10.1080/02681102.2018.1446412

Lewis, W. A. 1954. Economic development with unlimited supplies of labour. The Manchester School 22(2): 139-191. https://doi.org/10.1111/j.1467-9957.1954.tb00021.x

Lo, C. C., Ash-Houchen, W., \& Gerling, H. M. 2017. The double-edged sword of gender equality: A cross-national study of crime victimization. International Criminal Justice Review 27(4): 255-277. https://doi.org/10.1177/1057567717700492

Lwoga, E. T., \& Sangeda, R. Z. 2019. ICTs and development in developing countries: A systematic review of reviews. Electronic Journal of Information Systems in Developing Countries 85(1): e12060. https://doi.org/10.1002/isd2.12060

Makoza, F., \& Chigona, W. 2012. The livelihood outcomes of ICT use in microenterprises: The case of South Africa. The Electronic Journal of Information Systems in Developing Countries 53(1): 1-16. https://doi.org/10.1002/j.1681-4835.2012.tb00374.x

Maricic, M., Egea, J. A., \& Jeremic, V. 2019. A hybrid enhanced scatter search-composite i-distance indicator (eSS-CIDI) optimization approach for determining weights within composite indicators. Social Indicators Research 144(2): 497-537. https://doi.org/10.1007/s11205-018-02056-x

Mathew, V. 2010. Women entrepreneurship in Middle East: Understanding barriers and use of ICT for entrepreneurship development. International Entrepreneurship and Management Journal 6(2): 163-181. https://doi.org/10.1007/s11365-010-0144-1 


\section{ENTREPRENEURSHIP AND SUSTAINABILITY ISSUES}

ISSN 2345-0282 (online) http://jssidoi.org/jesi/ 2019 Volume 7 Number 2 (Decembre) http://doi.org/10.9770/jesi.2019.7.2(1)

Mattedi, A. P., Júnior, A. N. B., Dos Santos, F. T. C., \& Pereira, S. B. 2015. Desenvolvimento econômico, social e tecnológico: sob uma perspectiva dos indicadores. Rchunitau.Com.Br, 101-116. Retrieved from http://www.rchunitau.com.br/index.php/rch/article/view/284

Matthews, H., \& Field, K. 2001. Home zones: Children, neighbourhoods and the quality of life. Geography 86(2): 168-171. https://doi.org/10.1093/0198287976.001.0001

Mayer, A., Haas, W., \& Wiedenhofer, D. 2017. How countries' resource use history matters for human well-being: An investigation of global patterns in cumulative material flows from 1950 to 2010. Ecological Economics 134, 1-10. https://doi.org/10.1016/J.ECOLECON.2016.11.017

Mbuyisa, B., \& Leonard, A. 2017. The role of ICT use in SMEs towards poverty reduction: A systematic literature review. Journal of International Development 29(2): 159-197. https://doi.org/10.1002/jid.3258

Myrdal G. 1957. Economic theory and underdeveloped regions. London: Duckworth.

Naudé, W. 2013. Entrepreneurship and economic development: Theory, evidence and policy. IZA Discussion Paper 7507: 1-20. https://doi.org/10.1111/j.1540-6520.2009.00308.x

Naudé, W., Santos-Paulino, A., \& McGillivray, M. 2009. Vulnerability in developing countries. Unu-Wider 08(2): 3-5. Retrieved from https://collections.unu.edu/eserv/UNU:2548/ebrary9789280811711.pdf

North, D. C. 1990. Institutions and a transaction-cost theory of exchange. Perspectives on Positive Political Economy $182: 191$.

North, D. C. 2005. Understanding the process of economic change. Business History Review 79(4): 859. https://doi.org/10.2307/25097117

Ntemi, W. D., \& Mbamba, U. O. 2016. The relationship between electronic readiness and corruption reduction: Countrywide data analysis. Cogent Business \& Management 3(1). https://doi.org/10.1080/23311975.2016.1257555

Núñez-Cacho, P., Molina-Moreno, V., Corpas-Iglesias, F. A., \& Cortés-García, F. J. 2018. Family businesses transitioning to a circular economy model: The case of "Mercadona." Sustainability 10(2): 538. https://doi.org/10.3390/su10020538

Oosterlaken, I. 2012. The capability approach, technology and design: Taking stock and looking ahead, in Oosterlaken I., \& van den Hoven J. (Eds.). The capability approach, technology and design. Philosophy of engineering and technology (Vol. 5). Dordrecht: Springer, 3-26. https://doi.org/10.1007/978-94-007-3879-9 1

Oosterlaken, I. 2014. Technologies of choice? ICTs, development and the capabilities approach. Journal of Human Development and Capabilities 15(1): 102-103. https://doi.org/10.1080/19452829.2013.875737

Otioma, C., Madureira, A. M., \& Martinez, J. 2019. Spatial analysis of urban digital divide in Kigali, Rwanda. GeoJournal 84(3): 719-741 https://doi.org/10.1007/s10708-018-9882-3

Park, A. 2012. Crowdfunding a cure: The sick are getting strangers to pay their medical bills. Time 180(23): 22. Retrieved from http://www.ncbi.nlm.nih.gov/pubmed/23326967

Pearson, K. 1920. Notes on the history of correlation. Biometrika 13(1): 25-45. https://doi.org/10.1093/biomet/13.1.25

Perényi, Á., \& Losoncz, M. (2018). A systematic review of international entrepreneurship special issue articles. Sustainability 10(10): 3476. https://doi.org/10.3390/su10103476

Porter, M. E., \& Stern, S. 2013. Social Progress Index 2013, 1-153. Retrieved from http://www.avina.net/avina//wp content/uploads/2013/04/SocialProgressIndex2013.pdf

Porter, M. E., Stern, S., \& Green, M. 2017. Social Progress Index $2017 . \quad$ Retrieved from https://www.socialprogressindex.com/assets/downloads/resources/en/English-2017-Social-Progress-Index-Methodology$\underline{\text { Report_embargo-until-June-21-2017.pdf }}$

Poveda, S., \& Roberts, T. 2018. Critical agency and development: applying Freire and Sen to ICT4D in Zambia and Brazil. Information Technology for Development 24(1): 119-137. https://doi.org/10.1080/02681102.2017.1328656 


\section{ENTREPRENEURSHIP AND SUSTAINABILITY ISSUES}

ISSN 2345-0282 (online) http://jssidoi.org/jesi/ 2019 Volume 7 Number 2 (Decembre) http://doi.org/10.9770/jesi.2019.7.2(1)

Reynolds, P. D. 2017. Enhancing understanding of entrepreneurial phenomena: Ethnographic opportunities in PSED and GEM assessments.

Reynolds, P. D., Bosma, N., Autio, E., Hunt, S., De Bono, N., Servais, I., ... Chin, N. 2005. Global Entrepreneurship Monitor: Data collection design and implementation 1998-2003. Small Business Economics 24(3): 205-231. https://doi.org/10.1007/s11187-005$\underline{1980-1}$

Rifkin, J. 2014. The zero marginal cost society. Frankfurt: Palgrave Macmillan.

Robeyns, I. 2005. Selecting capabilities for quality of life measurement. Social Indicators Research 74(1): 191-215. https://doi.org/10.1007/s11205-005-6524-1

Robeyns, I. 2017. Wellbeing, freedom and social justice: The capability approach re-examined. Cambridge: Open Book Publishers. https://doi.org/10.11647/OBP.0130

Rostow W. 1960. The stages of economic growth: A non-communist manifesto. Cambridge: University Press.

Samoilenko, S., \& Osei-Bryson, K.-M. 2018. An analytical framework for exploring context-specific micro-economic impacts of ICT capabilities. Information Technology for Development 24(4): 633-657. https://doi.org/10.1080/02681102.2017.1336072

Samoilenko, S., \& Osei-Bryson, K. M. 2019. It should be there, but it is hard to find: Economic impact of ICT in Sub-Saharan economies, in: Krauss K., Turpin M., \& Naude F. (Eds.). Locally Relevant ICT Research. IDIA 2018. Communications in computer and information science (Vol. 933). Cham: Springer, 17-34 https://doi.org/10.1007/978-3-030-11235-6_2

Schumpeter, J. A. 1939. The theory of economic development: An inquiry into profits, capital, credit, interest, and the business cycle. New York: McGraw-Hill.

Sen, A. 1981. Poverty and famines. Oxford: Oxford University Press. https://doi.org/10.1093/0198284632.001.0001

Sen, A. 1985. Well-being, agency and freedom: The Dewey lectures 1984. The Journal of Philosophy 82(4): 169. https://doi.org/10.2307/2026184

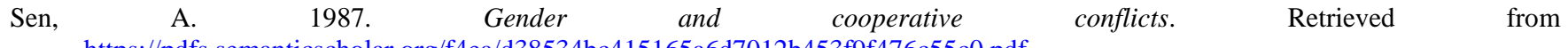
https://pdfs.semanticscholar.org/f4ea/d38534bc415165a6d7012b453f9f476c55c0.pdf

Sen, A. 1993. Capability and well-being, in Nussbaum, M., \& Sen, A. (Eds.). The quality of life. Oxford: Oxford University Press, $30-53$. https://doi.org/10.1093/0198287976.003.0003

Sen, A. 1995. Inequality reexamined. New York: Russell Sage Foundation. https://doi.org/10.1093/0198289286.001.0001

Sen, A. 1998. Capital Humano y Capacidad Humana. Cuadernos de Economía (Santafé de Bogotá) 17(29): 67-72. Retrieved from http://dialnet.unirioja.es/servlet/articulo?codigo=4934956\&info=resumen\&idioma=SPA

Sen, A. 1999. Development as freedom. Oxford: Oxford University Press.

Sen, A. 2005. Human rights and capabilities. Journal of Human Development 6(2): 151-166. https://doi.org/10.1080/14649880500120491

Sen, A. 2009. The idea of justice. Cambridge: Belknap Press of Harvard University Press.

Sen, A. 2010. The mobile and the world. Information Technologies \& International Development 6: 1-3. Retrieved from http://dev.itidjournal.org/index.php/itid/article/download/614/254

Shane, S., \& Venkataraman, S. 2000. The promise of entrepreneurship as a field of research. Academy of Management Review 25(1): 217226. https://doi.org/10.5465/AMR.2000.2791611

Socialprogressindex.org. 2018. Social Progress Imperative. Retrieved from https://www.socialprogress.org/download

Stanojević, A., \& Benčina, J. 2019. The construction of an integrated and transparent index of wellbeing. Social Indicators Research 143(3): 995-1015. https://doi.org/10.1007/s11205-018-2016-y 


\section{ENTREPRENEURSHIP AND SUSTAINABILITY ISSUES}

ISSN 2345-0282 (online) http://jssidoi.org/jesi/ 2019 Volume 7 Number 2 (Decembre) http://doi.org/10.9770/jesi.2019.7.2(1)

Stern, S., Wares, A., \& Epner, T. 2017. Índice de Progreso Social 2017: Informe metodológico. Retrieved from http://www.socialprogressimperative.org/create-an-index/?lang=es

Stern, S., Wares, A., Orzell, S., \& O’Sullivan, P. 2014. Social Progress Index 2014: Methodological Report. Social Progress Imperative. Retrieved from http://13i8vn49fibl3go3i12f59gh.wpengine.netdna-cdn.com/wp-content/uploads/2016/07/SPI-2016-Methodological$\underline{\text { Report.pdf }}$

Stiglitz, J. E., Sen, A., \& Fitoussi, J.-P. 2009. Report by the Commission on the Measurement of Economic Performance and Social Progress. Paris: Commission on the Measurement of Economic Performance and Social Progress. Retrieved from https://doi.org/10.2139/ssrn.1714428

Sugden, R., \& Sen, A. 2006. Commodities and capabilities. The Economic Journal 96(383): 820. https://doi.org/10.2307/2232999

Szabo, Z. K., \& Herman, E. 2013. Innovative entrepreneurship for economic development in EU. Procedia Economics and Finance 3, 268-275. https://doi.org/10.1016/s2212-5671(12)00151-7

Thapa, D., \& Saebø, Ø. 2014. Exploring the link between ICT and development in the context of developing countries: A literature review. The Electronic Journal of Information Systems in Developing Countries 64(1): 1-15. https://doi.org/10.1002/j.1681$\underline{4835.2014 . t b 00454 . \mathrm{x}}$

UNDP. (1990). Human development report 1990. Retrieved from https://doi.org/0-19-506481-X

UNDP. (1992). Human development $\quad$ report $\quad 1992 . \quad$ Retrieved http://hdr.undp.org/sites/default/files/reports/221/hdr_1992_en_complete_nostats.pdf

UNDP. (1993). Human development $\quad$ report $\quad 1993 . \quad$ Retrieved from http://hdr.undp.org/sites/default/files/reports/222/hdr_1993_en_complete_nostats.pdf

UNDP. (1998). Human development report 1998. Retrieved from http://www.undp.org/undp/hdro

UNDP. (1999). Human development report $1999 . \quad$ Retrieved http://hdr.undp.org/sites/default/files/reports/260/hdr_1999_en_nostats.pdf

UNDP. 2001. Human development report 2001: Making new technologies work for human development. Retrieved from http://hdr.undp.org/sites/default/files/reports/262/hdr 2001 en.pdf

UNDP. 2002. Human development report 2002: Deepening democracy in a fragmented world. Retrieved from https://doi.org/10.18356/b6670cee-en

UNDP. 2003. Human development report 2003: Millennium Development Goals: A compact among nations to end human poverty. New York: UNDP.

UNDP. 2007. Human development report 2007/2008: Fighting climate change: human solidarity in a divided world. New York: UNDP.

UNDP. 2013. Human development report 2013: The rise of the south human progress in a diverse world (Vol. 125). Retrieved from https://doi.org/10.1016/j.rmr.2010.03.023

UNDP. 2014. Human development report 2014: Sustaining human progress: Reducing vulnerabilities and building resilience. Retrieved from http://hdr.undp.org/sites/default/files/hdr14-summary-en.pdf

UNDP. (2015a). Human development report 2015. Work for Human Development. Retrieved from https://doi.org/ISBN: 978-92-1-1263985

UNDP. (2015b). Human development report 2015: Sustaining human progress: Reducing vulnerabilities and building resilience. Retrieved from

https://login.ezproxy.net.ucf.edu/login?auth=shibb\&url=http://search.ebscohost.com/login.aspx?direct=true\&db=edsgao\&AN=edsgc $\underline{1.397619208 \& \text { site }=e d s-\text { live } \& \text { scope }=\text { site }}$

UNDP. 2016. Human development report 2016: Human development for everyone. Retrieved from http://hdr.undp.org/sites/default/files/2016_human_development_report.pdf 


\section{ENTREPRENEURSHIP AND SUSTAINABILITY ISSUES}

ISSN 2345-0282 (online) http://jssidoi.org/jesi/ 2019 Volume 7 Number 2 (Decembre) http://doi.org/10.9770/jesi.2019.7.2(1)

Urbano, D., \& Alvarez, C. 2014. Institutional dimensions and entrepreneurial activity: An international study. Small Business Economics 42(4): 703-716. https://doi.org/10.1007/s11187-013-9523-7

Urbano, D., \& Aparicio, S. 2016. Entrepreneurship capital types and economic growth: International evidence. Technological Forecasting and Social Change 102, 34-44. https://doi.org/10.1016/J.TECHFORE.2015.02.018

Urbano, D., Aparicio, S., \& Audretsch, D. B. 2019. Twenty-five years of research on institutions, entrepreneurship, and economic growth: What has been learned? Small Business Economics 52(1): 21-49. https://doi.org/10.1007/s11187-018-0038-0

Urbano, D., Aparicio, S., \& Querol, V. 2016. Social progress orientation and innovative entrepreneurship: An international analysis. Journal of Evolutionary Economics 26(5): 1033-1066. https://doi.org/10.1007/s00191-016-0485-1

Van Hemmen, S., Alvarez, C., Peris-Ortiz, M., \& Urbano, D. 2015. Leadership styles and innovative entrepreneurship: An international study. Cybernetics and Systems 46(3-4): 271-286. https://doi.org/10.1080/01969722.2015.1012896

Walsham, G. 2017. ICT4D research: Reflections on history and future agenda. Information Technology for Development 23(1): 18-41. https://doi.org/10.1080/02681102.2016.1246406

Wennekers, S., Van Wennekers, A., Thurik, R., \& Reynolds, P. D. 2005. Nascent entrepreneurship and the level of economic development. Small Business Economics 24(3): 293-309. https://doi.org/10.1007/s11187-005-1994-8

Wooldridge, J. M. 2009. la econometría Introducción a Un enfoque moderno (4th ed.). Boston: South-Western Cengage Learning.

World Bank. 2013. World development indicators 2013 (English). Washington, DC: World Bank Group. http://documents.worldbank.org/curated/en/449421468331173478/World-development-indicators-2013

World Bank. 2018. World $\quad$ Development $\quad$ Indicators. Retrieved https://databank.worldbank.org/data/reports.aspx?source=2\&series=SP.POP.TOTL\&country=

World Economic Forum. 2015. The global information technology report 2015 (Vol. 8). Retrieved from http://www3.weforum.org/docs/WEF_GITR2015.pdf

World Economic Forum. (2016a). Networked Readiness Index. The Global Information Technology Report 2016. Retrieved from http://reports.weforum.org/global-information-technology-report-2016/networked-readiness-index/

World Economic Forum. (2016b). The Global Information Technology Report 2016. World Economic Forum. Retrieved from http://www3.weforum.org/docs/GITR2016/GITR_2016_full report_final.pdf

Zheng, Y., Hatakka, M., Sahay, S., \& Andersson, A. (2018). Conceptualizing development in information and communication technology for development (ICT4D). Information Technology for Development 24(1): 1-14. https://doi.org/10.1080/02681102.2017.1396020 


\section{ENTREPRENEURSHIP AND SUSTAINABILITY ISSUES}

ISSN 2345-0282 (online) http://jssidoi.org/jesi/ 2019 Volume 7 Number 2 (Decembre) http://doi.org/10.9770/jesi.2019.7.2(1)

Bladimir DE LA HOZ ROSALES holds a master's degree in Business Development and is currently a professor at the University of Magdalena, Colombia. His research focuses on human development, entrepreneurship, and information and communication technologies.

ORCID ID: https://orcid.org/0000-0002-4900-9693

José CAMACHO BALLESTA holds a PhD in Applied Economics and is currently a professor in the Department of Spanish and International Economics and the Director of the Regional Development Institute at the University of Granada, Spain. He is also a member of the Andalusian Academy of Regional Science and the author of several articles on regional development. His research focuses on productive systems, regional development, social policies and the labor market, economic indicators, and the European Union.

ORCID ID: https://orcid.org/0000-0002-9786-5400

Ignacio TAMAYO TORRES holds a PhD in Management and is currently a Professor in the Management Department of the University of Granada, Spain. He has authored several journal articles on technology analysis and strategic management. His research focuses on strategic management, corporate social responsibility, and human development.

ORCID ID: https://orcid.org/0000-0003-3823-6484

Register for an ORCID ID:

https://orcid.org/register

Copyright (C) 2019 by author(s) and VsI Entrepreneurship and Sustainability Center

This work is licensed under the Creative Commons Attribution International License (CC BY).

http://creativecommons.org/licenses/by/4.0/

(c) (i) Open Access 